$\mathcal{E}_{\text {Iransport Forum }}^{\text {International }}$

\title{
Institutional and Political Determinants of Private Participation in Infrastructure
}

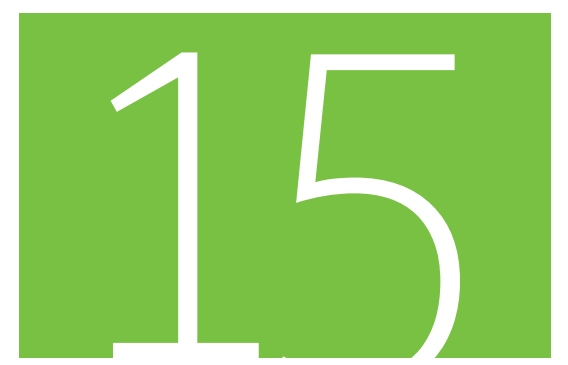

Discussion Paper 2014 • 15

Marian Moszoro, Gonzalo Araya, Fernanda Ruiz-Nuñez and Jordan Schwartz The World Bank,

Washington D.C., USA 


\title{
International Transport Forum
}

\section{Institutional and Political Determinants of Private Participation in Infrastructure}

\author{
Discussion Paper $N^{0}$ 2014-15
}

Prepared for the Roundtable:

\section{Public Private Partnerships for Transport Infrastructure: Renegotiations, how to approach them and economic outcomes}

27-28 October 2014,

George Mason University, Washington D.C., USA

Marian Moszoro, Gonzalo Araya,
Fernanda Ruiz-Nuñez and Jordan Schwartz

$\underline{\text { Revised October } 2014}$

\footnotetext{
${ }^{1}$ Gonzalo Araya, a former Junior Professional Associate in the Sustainable Development Department of the World Bank's Latin America and Caribbean Region, now at the Ministry of Transport and Telecommunications of Chile; Marian Moszoro is a Professor of Finance at Kozminski University, Poland, Visiting Scholar at the University of California, Berkeley, a Senior Financial Consultant at the World Bank, and former Undersecretary of Finance of Poland; Fernanda Ruiz Nuñez is a Senior Infrastructure Economist at the Infrastructure Policy Unit, PPPs Group at the World Bank; and Jordan Schwartz is Manager at the Infrastructure Policy Unit, PPPs Group at the World Bank, based at the Bank's Center for Infrastructure \& Urban Development in Singapore. The authors'email addresses are: gonzaloarayaa@gmail.com,mmoszoro@berkeley.edu, fruiznunez@worldbank.org, and jschwartz3@worldbank.org.
} 


\section{THE INTERNATIONAL TRANSPORT FORUM}

The International Transport Forum at the OECD is an intergovernmental organisation with 54 member countries. It acts as a strategic think-tank, with the objective of helping shape the transport policy agenda on a global level and ensuring that it contributes to economic growth, environmental protection, social inclusion and the preservation of human life and well-being. The International Transport Forum organises an annual summit of Ministers along with leading representatives from industry, civil society and academia.

The International Transport Forum was created under a Declaration issued by the Council of Ministers of the ECMT (European Conference of Ministers of Transport) at its Ministerial Session in May 2006 under the legal authority of the Protocol of the ECMT, signed in Brussels on 17 October 1953, and legal instruments of the OECD.

The Members of the Forum are: Albania, Armenia, Australia, Austria, Azerbaijan, Belarus, Belgium, Bosnia and Herzegovina, Bulgaria, Canada, Chile, People's Republic of China, Croatia, Czech Republic, Denmark, Estonia, Finland, France, Former Yugoslav Republic of Macedonia, Georgia, Germany, Greece, Hungary, Iceland, India, Ireland, Italy, Japan, Korea, Latvia, Liechtenstein, Lithuania, Luxembourg, Malta, Mexico, Republic of Moldova, Montenegro, the Netherlands, New Zealand, Norway, Poland, Portugal, Romania, Russian Federation, Serbia, Slovak Republic, Slovenia, Spain, Sweden, Switzerland, Turkey, Ukraine, United Kingdom and United States.

The International Transport Forum's Research Centre gathers statistics and conducts co-operative research programmes addressing all modes of transport. Its findings are widely disseminated and support policymaking in Member countries as well as contributing to the annual summit.

\section{Discussion Papers}

The International Transport Forum's Discussion Paper Series makes economic research, commissioned or carried out at its Research Centre, available to researchers and practitioners. The aim is to contribute to the understanding of the transport sector and to provide inputs to transport policy design.

ITF Discussion Papers should not be reported as representing the official views of the ITF or of its member countries. The opinions expressed and arguments employed are those of the authors.

Discussion Papers describe preliminary results or research in progress by the author(s) and are published to stimulate discussion on a broad range of issues on which the ITF works. Comments on Discussion Papers are welcomed, and may be sent to: International Transport Forum/OECD, 2 rue André-Pascal, 75775 Paris Cedex 16, France.

For further information on the Discussion Papers and other JTRC activities, please email: itf.contact@oecd.org

The Discussion Papers can be downloaded from:

www.internationaltransportforum.org/jtrc/DiscussionPapers/jtrcpapers.html

The International Transport Forum's website is at: www.internationaltransportforum.org

This document and any map included herein are without prejudice to the status of or sovereignty over any territory, to the delimitation of international frontiers and boundaries and to the name of any territory, city or area. 


\section{Table of Contents}

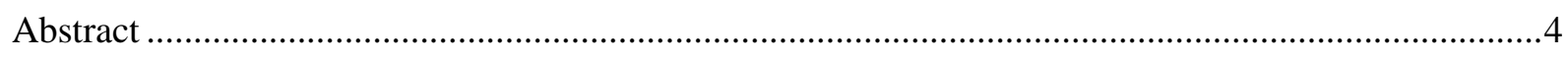

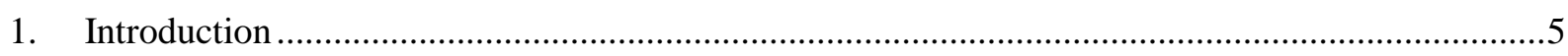

2. Theoretical Background to Understand the Determinants of PPI ................................................8

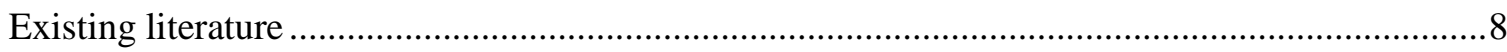

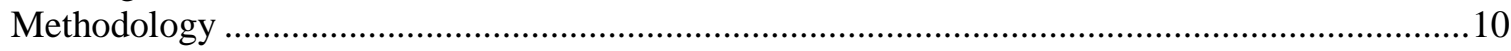

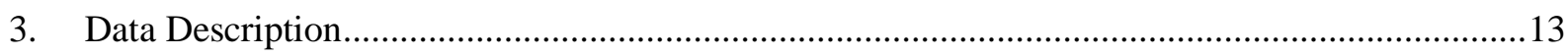

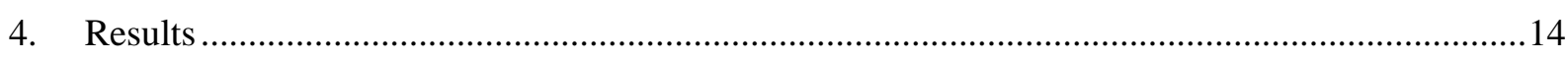

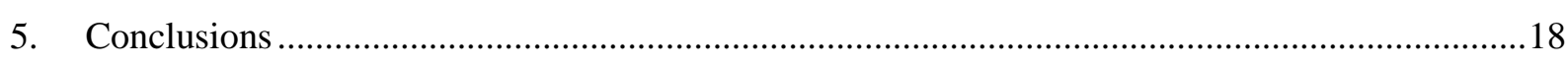

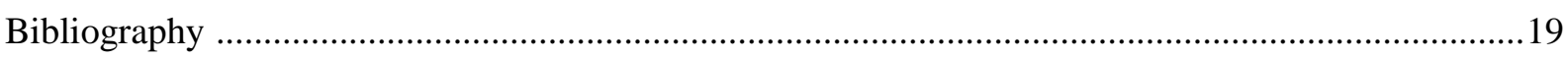

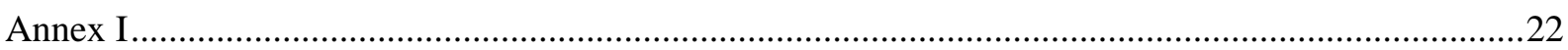

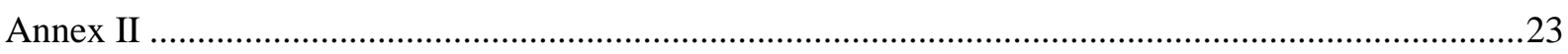

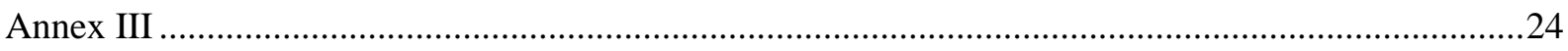

Washington D.C., October 2014 


\begin{abstract}
We assembled a large panel of project-level technical and financial data and country-level economic, institutional, political, and governance variables to assess the determinants of private financing of infrastructure in emerging markets and developing economies. Controlling for economic characteristics, we find that overall private participation of infrastructure financing increases with freedom from corruption, rule of law, quality of regulations, and decreases with court disputes. We provide plausible explanations of deviations from this pattern when data is disaggregated at the sectoral level. We also found that legal systems - types of democracy or dictatorship - do not play a role in whether the private sector invests in infrastructure. Our results do not vary when controlling for income inequality and across quartiles of experience, country wealth, and wealth per capita. The study shows that upstream "enabling" institutions, policies, and regulations and sector economics need to be addressed simultaneously to facilitate private infrastructure investment financing.
\end{abstract}

JEL Classification: D73, H54, L33, L51, R42

Keywords: Private Participation in Infrastructure, Bureaucracy, Corruption, Regulation, Rule of Law

Moszoro: University of California, Berkeley and Kozminski University, Poland, mmoszoro@ berkeley.edu; Araya: Ministry of Transport and Telecommunications of Chile, gonzaloarayaa@gmail.com; Ruiz-Nuñez: PPPs Group at the World Bank, fruiznunez@worldbank.org; Schwartz: PPPs Group at the World Bank, jschwartz3@worldbank.org. The authors are grateful to Alex Jett for his support with the PPI Database, Francesca Guiso for assisting with the data analysis, and Conor Healy for sharing digitalized data on Disputes. The findings, interpretations, and conclusions expressed herein do not necessarily reflect the views of the Board of the Executive Directors of the World Bank or the governments they represent. 


\section{Introduction}

The links between infrastructure and development are well established. They include the impact of infrastructure on poverty alleviation, equity, growth, and specific development outcomes such as job creation, market access, health, and education (Straub 2008; Calderón and Servén 2004, 2008, 2010). These relationships are complex and dynamic; even with respect to growth and job creation; infrastructure's effects are felt through multiple channels. ${ }^{2}$ The demand for infrastructure is rising with the accelerating pace of globalization and urbanization. Every month in the developing world, more than five million people migrate to urban areas. This trend is compounded by the growing need for low $\mathrm{CO}_{2}$ and climate-resilient investments to combat the challenges of climate change (Fay and Toman 2010; Bhattacharya and Romani 2013).

As a result of the fiscal constraints in many economies caused by the onset of the global financial crisis, government budgets - traditionally the major source of financing for infrastructure - cannot alone be expected to finance the infrastructure needs in emerging markets and developing economies (EMDEs). Yet the volume of private participation in financing infrastructure projects in EMDEs remains modest.

While private sector financial commitments to infrastructure projects have risen to about USD 181 billion per year in EMDEs, this is less than $20 \%$ of the overall current infrastructure investment in these economies. There has been an important increase in private participation in infrastructure financing (PPI) over the last two decades. ${ }^{3}$ Annual commitments ${ }^{4}$ to PPI projects have increased from USD 22 million in 1990 to USD 181 million in 2012 (see Figure 1). Importantly, most of this growth since 2000 has been mainly in the energy and transport sectors (see Figure 2).

\footnotetext{
${ }^{2}$ See Agénor and Moreno-Dodson (2006) for an overview and Estache et al. (2013) and Schwartz et al. (2009) for a treatment of infrastructure's effects on jobs and growth.

${ }^{3}$ Private participation in infrastructure can be treated as equivalent to public-private partnerships.

${ }^{4}$ Investment in this paper refers to the resources the project company commits to invest in facilities during the contract period. Investments can be either in new facilities or in the expansion and modernization of existing facilities. Data entry varies across sectors: For projects other than telecommunications and large energy utilities, the total cost of developing or expanding the facility during the contract period is entered as investment data during the year of financial closure (for which data are typically available). For telecommunications projects and some large energy utilities, annual investments on facility expansion and modernization are entered as investment data in the year of investment when information is publicly available. Investments are recorded in millions of US dollars in either the year of financial closure or the year of investment as indicated above.
} 
Figure 1: Private Investment in Infrastructure in Low and Middle Income Countries

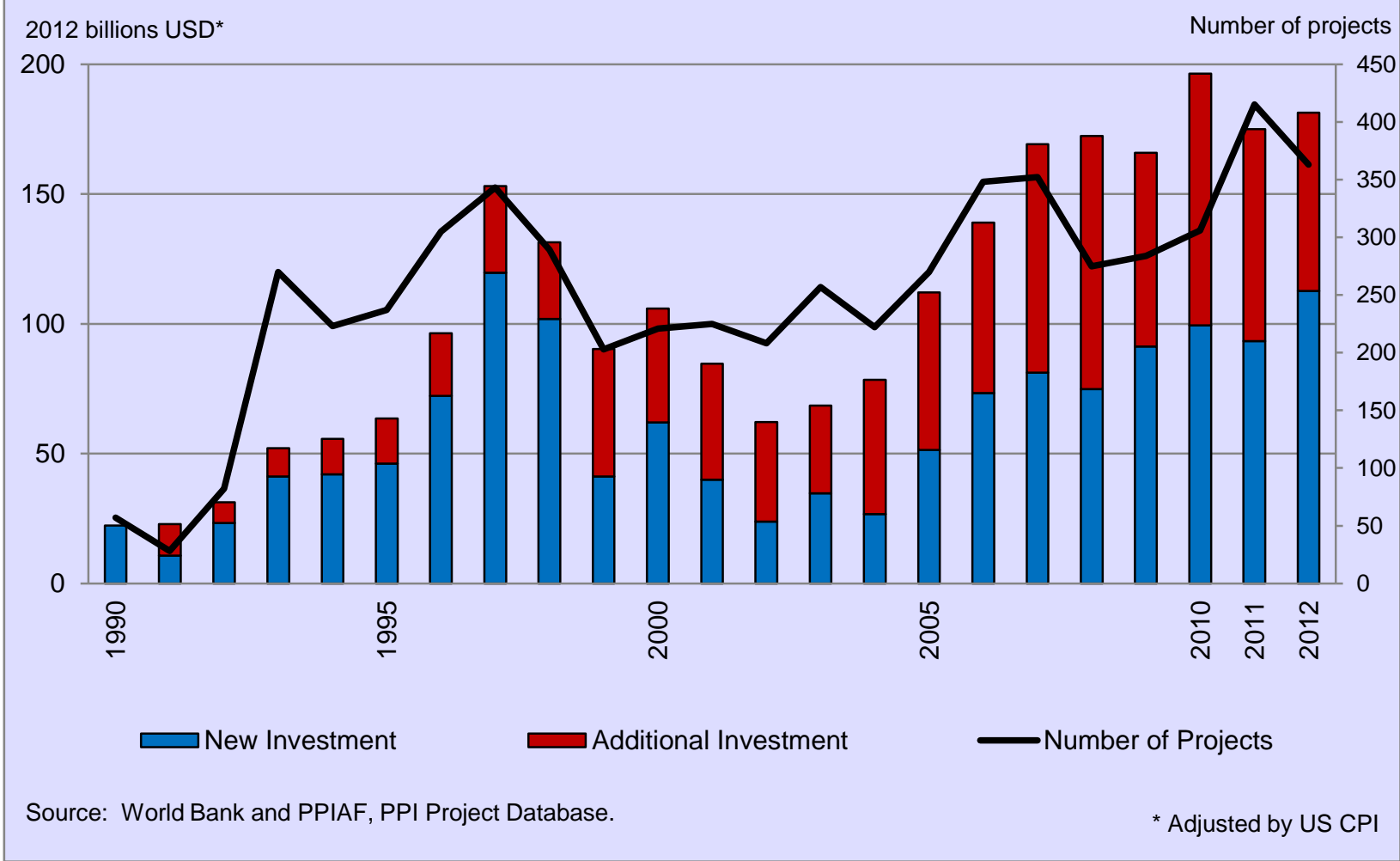




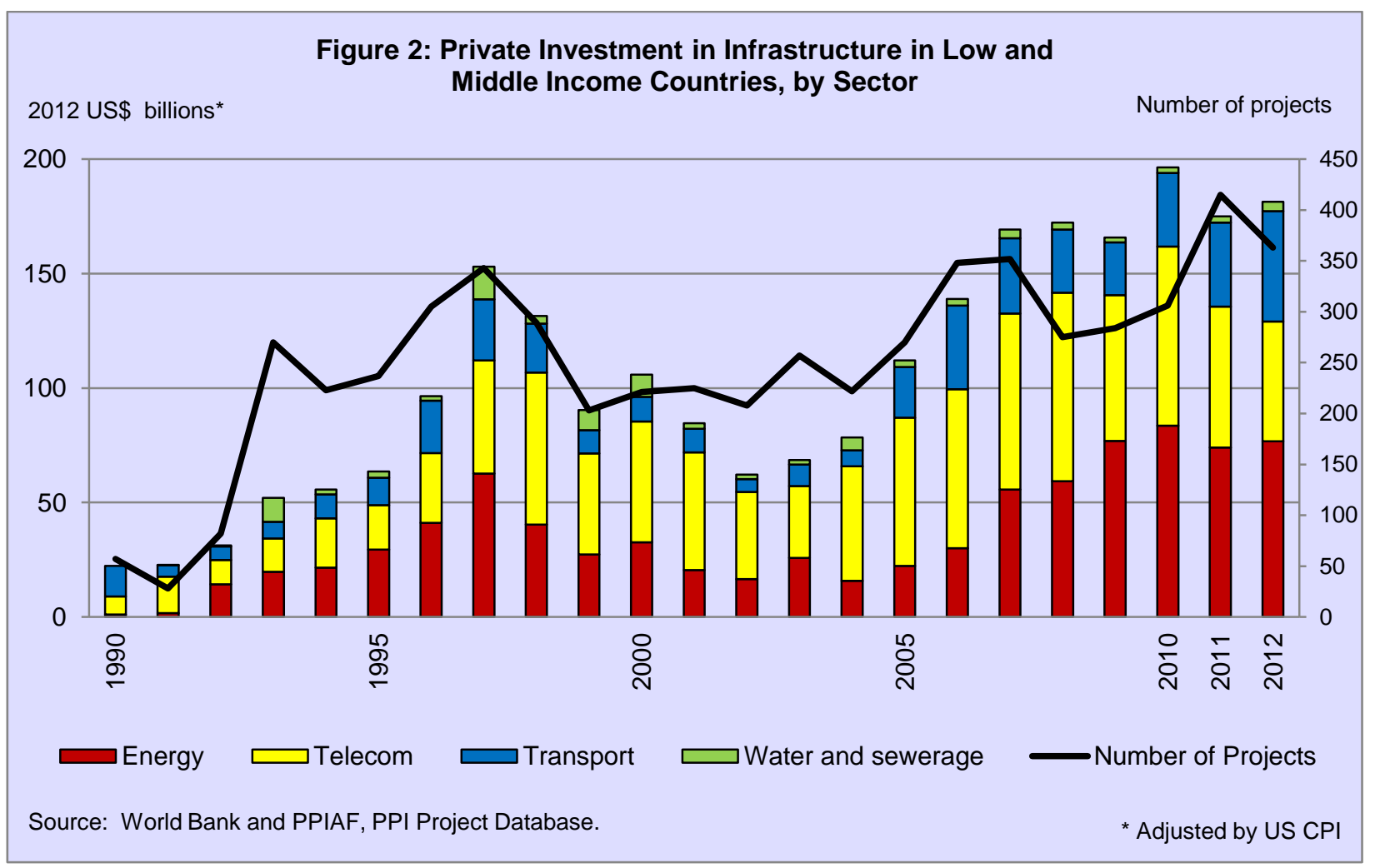

There are a number of current and emerging challenges that are expected to undermine the attractiveness of long-term private investments such as furthering infrastructure. The weakness in and deleveraging of commercial banks and the regulatory constraints such as Basel III is likely to persist into the medium term, which implies a growing mismatch between the time horizon of available capital and that of productive long-term investment projects (World Bank, 2013).

Even under more normal credit conditions, the costs and risks faced by private investors in infrastructure are high, particularly in EMDEs, where economic and financial conditions tend to be weaker and less stable. Another critical and overarching pre-condition to attract private investors is an enabling institutional framework, including peace and stability, the rule of law, good governance with accountability and transparency, the absence of corruption, clear property rights, and enforceable contracts.

From a public policy perspective, given the positive economic, social, and environmental externalities that quality infrastructure can provide, efforts to lower the overall riskiness of infrastructure investments and enhance the availability of efficient risk-sharing instruments can have important implications in efficiency and distribution. At the same time, there is a need to ensure that efforts to encourage private sector participation in infrastructure offer optimal benefits but do not impose an inappropriate burden on the public sector. 
Against this background, this paper aims to assess the determinants of private financing of infrastructure with a special focus on institutional, political, and governance characteristics. The paper then identifies areas in which additional efforts are required if the private sector were to play a larger role in financing infrastructure development in EMDEs.

\section{Theoretical Background to Understand the Determinants of PPI}

\section{Existing literature}

There is considerable economic and financial literature attempting to explain the determinants of investment and the relationship between investment and risk. Most of the theoretical literature points to access to capital, investment efficiency, the social (as opposed to the financial) discount rate, operational efficiency, bundling of investment and operations, risk allocation, and contract flexibility as the main economic drivers of private investment in infrastructure (see Annex I for a literature taxonomy and mapping of these drivers).

The empirical literature is focused on foreign direct investment rather than infrastructure investments, and most of the works utilize cross-country specifications. For example, Chakrabarti (2001) concludes that market size is a robust determinant of FDI, and Nunnenkamp (2002) identifies exchange rate, openness, growth rate, and trade balance as determinants of overall investment levels.

The literature on infrastructure investments and risk is thinner. Araya et al. (2013) analyses the relationship between private participation in infrastructure and country risk. They show that a difference of one standard deviation in a country's sovereign risk score is associated with a $27 \%$ increase in the probability of having private participation in infrastructure commitment and a $41 \%$ higher level of investment in dollar terms with the energy sector (among infrastructure sectors) and concessions (among contractual types). They also show that conflict-affected countries typically require six to seven years to attract significant levels or forms of private investments in infrastructure from the day that the conflict is officially resolved. Private investments in sectors in which assets are more difficult to secure — such as water, power distribution, or roads — are slower to appear or simply never materialize.

Hammami et al. (2006) use the World Bank PPI Database to analyze the determinants of PPI and conclude that lower levels of corruption and more effective rule of law are associated with more Public-Private Partnership projects. This study captures the effect on the number of projects committed, but not the investment levels per se, leaving room for further study, especially if we consider that bigger projects (committing more resources) may be more sensitive to the risk of the country. 
The empirical evidence on determinants of PPIs uses a cross-country panel regression approach, looking at whether indicators of macroeconomic stability, measures of institutional and regulatory quality, and a variety of other controls impact the total amount of PPI received by a country. For example, Pragal (2003) and Kirpatrick et al. (2006) look at the importance of the regulatory framework as a determinant of PPI respectively for Latin America and the Caribbean (LAC) and the broader set of developing countries. Pragal (2003) finds that the most significant determinant of PPI is the passage of legislation liberalizing the investment regime, while Kirpatrick et al. (2006) find that institutional framework and regulation matter most. Similarly, Banerjee et al. (2006) look at the question of whether institutions matter for PPI. While their results indicate that property rights and bureaucratic quality play a significant role in promoting PPI, they find that countries with higher levels of corruption attract more PPIs.

A study by Tewodaj (2013) analyse the determinants of private participation in infrastructure comparing Sub-Saharan Africa (SSA) with low and middle income countries (LMICs). The study finds that PPI investments in LMICs seem to be, in principle, determined by the expected factors (i.e. larger, open, more developed democracies with lower tax burden and more stable macroeconomic environment receive more PPI), PPI into SSA countries is - from a social planner's perspective sub-optimally allocated. In particular, when it comes to larger PPI investments the findings suggest that corrupt countries with inefficient governments seem to attract more PPI in infrastructure. Basilio (2011) shows that market size and purchasing power are critical determinants of infrastructure flows. The institutional quality matters mostly for the decision to invest in emerging countries, but it is less important with regard to the intensity of the investment than financial and economic conditions.

Jensen et al. (2005) analyze the institutional determinants of private sector participation in the water and sanitation sector in 60 developing countries. The regression results provide support for the hypotheses that PPI is greater in larger markets where the ability to pay is higher and where governments are fiscally constrained. The protection of property rights and the quality of the bureaucracy emerge as the most important institutions that encourage PPI. Gasmi et al. (2010) assess the extent the level of development of financial sector is a determinant of private investment in the power sector in 37 developing countries. The results suggest that investors tend to take countries' governance quality into account in their decisions to invest. The empirical results highlight that the development of the financial sector also plays a significant role in private investors' decisions to enter infrastructure sectors.

The objective of this paper is to contribute to the literature by disentangling the relevant institutional, political, and governance determinants of country risk at a granular level through providing a theoretical framework to derive the testable hypotheses, using a novel dataset on quality of governance 
and on number of PPI disputes, ${ }^{5}$ and extending previous analyses with a cross-country panel for 19842012 period. $^{6}$

\section{Methodology}

To identify the determinants of PPI, we construct a toy model that captures institutional and political variables along with economic and financial variables.

Let's assume a three-stage-investment, predictable cash flows, and terminal value model:

1. In $\mathrm{t}_{0}$, the public agent and/or private investor invest $I$ with certainty (construction risks are absorbed by the constructor; there may be a differential in investment efficiency though);

2. In $\mathrm{t}_{1,2, \ldots, \mathrm{n}}$, predictable cash flows $C F$ are realized (in financial modeling, these are cash flows broken down year by year, e.g., 5-8 years);

3. In $t_{n+1, \ldots, \infty}$, the terminal value $(T V)$ is realized with uncertainty (in a Discount Cash Flow $-\mathrm{DCF}-$ valuation, the $T V$ accounts for ca. 40-70\% of the present value of the asset, depending on the discount rate $)^{7}$;

4. The public agent, unlike the private investor, can receive transfers $T R$ conditional on states of $T V$ : if $T V$ is low, the public agent can levy taxes from the public at large and subsidize the project; if $T V$ is high, the public agent will lower prices (directly or through regulation) to gain political support;

5. $T R$ have an expected value of zero, so that the public agent's $T V+$ transfers $(T R)$ have the same expected value, but lower volatility than $T V$ alone; i.e., $\mathrm{E}(T V+T R)=\mathrm{E}(T V)$ and $\mathrm{SD}(T V+T R)<$ $\mathrm{SD}(T V)$.

The $T V$ is relevant for the private investor inasmuch as she has a stake in the long-term operations of the asset. For institutional arrangements (e.g. joint ventures), the private investor has an interest in preserving the value of the assets. For finite-time contractual arrangements (e.g., concessions), the salvage value of the asset for the private investor is not greater than its market value. Therefore, from the public agent's standpoint, the volatility of the $T V$ increases in private ownership and decreases in contract duration, in line with assumption (5).

\footnotetext{
${ }^{5}$ Previous literature has only used the number of calendar days to resolve a payment through courts from Djankov et al. (2007), but not PPI disputes specifically.

${ }^{6}$ The latest study is by Tewodaj (2013) and uses data up to 2008 .

${ }^{7}$ The following stylized numerical example illustrates this point: Let us assume a series of USD 100 perpetual cash flows $(C F)$ discounted at a rate $(r)$ of $10 \%$ annually. The first 10 years $(n)$ account for $61 \%$ of the present value, while the terminal value-i.e., the cash flows from year 11 onwards-for $39 \%$ of the present value. The shorter the period accounted for the foreseeable cash flows, the lower the discount rate, and the higher the terminal value cash flows growth in perpetuity are, the higher the proportion the terminal value will have in the present value. For example, for $n=5$ and $r=7 \%$, the terminal value represents $71 \%$ of the present value.
} 
From Assumptions (1)-(5), the Net Present Value for public investments equals:

$$
N P V_{p u}=-I_{p u}+\sum_{j=1}^{n} \frac{C F_{p u, j}}{\left(1+r_{p u}\right)^{j}}+\frac{T V+T R \mid T V}{\left(1+r_{p u}\right)^{n}}
$$

and for private investments:

$$
\begin{aligned}
N P V_{p r}=-I_{p r} & +\sum_{j=1}^{n} \frac{C F_{p r, j}}{\left(1+r_{p u}\right)^{j}}+\frac{T V}{\left(1+r_{p u}+r_{\text {premium }}\right)^{n}}= \\
& =-I_{p r}+\sum_{j=1}^{n} \frac{C F_{p r, j}}{\left(1+r_{p u}\right)^{j}}+\frac{T V}{\left(1+r_{p r}\right)^{n}}
\end{aligned}
$$

where $r_{p u}$ is the social discount rate and $r_{p r}$ is the private discount rate equal to the social discount rate plus a risk premium for higher variance (higher beta) of $T V$ without $T R$. Under these assumptions the discount rate during the predictable period $n$ is the same for both the public and private sectors; the risk premium is only realized in the terminal value The risks during the predictable period are absorbed in the expected value of the cash flows, not the discount rate. If the distribution of the cash flows is unknown, then $n$ should be shortened and the discount rate adjusted.

Arguably, if investments and cash flows are different under public and private provision, so are cash flows after period $n$ captured in the terminal value $T V$. For simplicity, we assume that $T V$ are equal under public and private provision (secular trend) and all rents from the private to the public sector are extracted through transfers $T R$, in accordance with assumption (4).

At the margin (i.e. where the choice between traditional procurement and PPI is indifferent), $N P V_{p u}=$ $N P V_{p r}$, therefore:

$$
\begin{gathered}
-I_{p u}+\sum_{j=1}^{n} \frac{C F_{p u, j}}{\left(1+r_{p u}\right)^{j}}+\frac{T V+T R \mid T V}{\left(1+r_{p u}\right)^{n}}=-I_{p r}+\sum_{j=1}^{n} \frac{C F_{p r, j}}{\left(1+r_{p u}\right)^{j}}+\frac{T V}{\left(1+r_{p r}\right)^{n}} \\
I_{p u}-I_{p r}+\sum_{j=1}^{n} \frac{C F_{p r, j}}{\left(1+r_{p u}\right)^{j}}-\sum_{j=1}^{n} \frac{C F_{p u, j}}{\left(1+r_{p u}\right)^{j}}=\frac{T V+T R \mid T V}{\left(1+r_{p u}\right)^{n}}-\frac{T V}{\left(1+r_{p r}\right)^{n}}
\end{gathered}
$$

Since $\operatorname{SD}\left(N P V_{p u}\right)<\operatorname{SD}\left(N P V_{p r}\right)$, in equilibrium $r_{p u}<r_{p r}$ (conf. CAPM; otherwise no investor would invest in a riskier project).

Normalizing by $I_{p u}-\sum_{j=1}^{n} C F_{p u, j} /\left(1+r_{p u}\right)^{j}=(T V+T R \mid T V) /\left(1+r_{p u}\right)^{n}$ : 


$$
\frac{I_{p r}-\sum_{j=1}^{n} \frac{C F_{p r, j}}{\left(1+r_{p u}\right)^{j}}}{I_{p u}-\sum_{j=1}^{n} \frac{C F_{p u, j}}{\left(1+r_{p u}\right)^{j}}}=\frac{T V \cdot\left(1+r_{p u}\right)^{n}}{(T V+T R \mid T V) \cdot\left(1+r_{p r}\right)^{n}}
$$

Given that $T R$ is a mean-preserving spread $[\mathrm{E}(T R)=0]$,

$$
\frac{I_{p r}-\sum_{j=1}^{n} \frac{C F_{p r, j}}{\left(1+r_{p u}\right)^{j}}}{I_{p u}-\sum_{j=1}^{n} \frac{C F_{p u, j}}{\left(1+r_{p u}\right)^{j}}}=\left(\frac{1+r_{p u}}{1+r_{p r}}\right)^{n}
$$

i.e. the preference for private participation in infrastructure will be given by:

$$
\frac{\sum_{j=1}^{n} \frac{C F_{p r, j}}{\left(1+r_{p u}\right)^{j}}-I_{p r}}{\sum_{j=1}^{n} \frac{C F_{p u, j}}{\left(1+r_{p u}\right)^{j}}-I_{p u}}+\left(\frac{1+r_{p u}}{1+r_{p r}}\right)^{n}>0
$$

\begin{tabular}{|c|c|c|c|}
\hline Variable & Meaning & 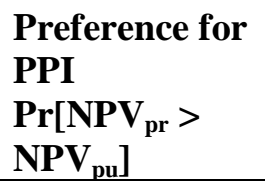 & Captured econometrically by \\
\hline $1-I_{p r} / I_{p u}$ & Investment efficiency & + & $\begin{array}{l}\text { Country dummies and subsample sector } \\
\text { regressions; GDP per capita controls }\end{array}$ \\
\hline$C F_{p r} / C F_{p u}$ & $\begin{array}{l}\text { Productivity } \\
\text { differential }\end{array}$ & + & $\begin{array}{l}\text { Country dummies and subsample sector } \\
\text { regressions; GDP growth control }\end{array}$ \\
\hline$n$ & $\begin{array}{l}\text { Industry stability } \\
\text { (inverse of industry } \\
\text { risk) }\end{array}$ & + & $\begin{array}{l}\text { Subsample sector regressions; regulatory } \\
\text { quality }\end{array}$ \\
\hline$r_{p u} / r_{p r}$ & $\begin{array}{l}\text { Political stability } \\
\text { (inverse of political } \\
\text { risk) }\end{array}$ & + & $\begin{array}{l}\text { Political variables: rule of law, corruption } \\
\text { perception, regulatory quality, and } \\
\text { number of disputes; corporate taxation } \\
\text { and country exchange rate volatility } \\
\text { controls }\end{array}$ \\
\hline
\end{tabular}

This toy model yields the following comparative statics:

Controlling for economic and industry factors, we derive a number of testable predictions:

Prediction 1: An increase in the rule of law — following North and Weingast (1999) — will be associated with a lower differential in the public and private discount rates and thus higher PPI. 
Prediction 2: An increase in regulatory quality will be associated with higher predictability of cash flows and thus higher PPI.

Prediction 3: An increase in freedom from corruption will be associated with a lower political risk premium and thus higher PPI.

Prediction 4: An increase in the number of disputes will be associated with a higher political risk premium and thus lower PPI.

\section{Data Description}

Data is an unbalanced panel assembled from the World Bank's Private Participation in Infrastructure dataset, Quality of Government dataset, UNCTAD Database of Treaty-based Investor-State Dispute Settlement Cases, and country-level economic variables from the World Development Indicators Database.

In order to obtain PPI levels, we utilized the World Bank PPI Database. This source offers detailed information by year, country, sector and form of public-private partnership. Within sectorial categories, it distinguishes among primary and secondary sectors by investment. ${ }^{8}$ It also provides the form of private investments, so we can distinguish between Greenfield projects and concessions of existing assets among other types of partnerships and investments.

The database, however, captures both public contributions to the infrastructure investments as well as private contributions. That is, the database notes total project size in commitments, later adjusted to actual disbursements, investments, or transfers, where information is available. Those commitments combine private and, in many cases, public sources. Only projects that have come to financial closure are included in the database. If a purely public investment is carried out in tandem with a private operator or a private management contractor, the database does not include them. All project figures are noted in the year that the project comes to financial closure.

For the purpose of this paper, the PPI database is an appropriate source of information because it reports the commitments of the investments for each year by country and by sector once a contract has come to financial closure; that is, a license, sale, concession, lease, BOT, or other contractual agreement is signed by both parties and financial arrangement have been secured. Having the commitments instead of the actual investments allows us to establish a clearer relationship between investments and institutional, political, and governance variables at a given point in time. The decision

\footnotetext{
${ }^{8}$ As examples, Energy and Transport are "primary sectors," whereas Electricity Distribution and Airports are "secondary sectors."
} 
of investing (commitment) and the willingness of financiers to come to closure on that commitment are made, inter alia, in the context of the political conditions, economic performance, sovereign credit worthiness, and fear of expropriation at the time of financial closure. Because there may be exogenous reasons for differentiation between an original commitment to invest and the eventual disbursement levels - including external shocks, canny renegotiations, or changes in tariffs or relative prices - the best time to value an investment relative to country risk is the moment at which the commitment comes to financial closure.

Taking the data from the PPI database, we gather information regarding 130 developing countries from 1990 to 2010. The panel data were complemented by data from World Development Indicators with variables such as GDP, GDP growth, inflation, country openness, and population.

The Quality of Governance Standard Database (Teorell et al., 2013) is a panel data that draws on a number of freely available data sources related to quality of governance and its correlates. This is our main source for the following variables: freedom from corruption, rule of law, quality of regulations, bureaucracy quality and political regimen, parliamentary democracy, mixed (semi-presidential) democracy, presidential democracy, civilian dictatorship, military dictatorship, and royal dictatorship. A detailed description of these variables is presented in Annex II.

Furthermore, we rely on the UNCTAD Database of Treaty-based Investor-State Dispute Settlement Cases to construct the variables on a number of disputes and average time to solve them by sector and country. This database has 394 observations covering disputed cases pending and concluded, which were disclosed by the parties or arbitral institutions from 1987 to 2010.

Summary statistics and the correlation of independent variables are presented in Annex III, Tables 1 and 2. 


\section{Results}

The model is specified in logarithms. We use a moving average of 15 years for water projects, 10 years for energy (plants and transmission) projects, 8 years for transport projects, and 5 years for telecom projects - roughly $1 / 3$ of the depreciation time estimated by the World Bank, i.e. arguably an approximation of refurbishing time - to account for the fact that data is on discrete observations of commitments.

We explore the intensity of the different determinants given that a country has received private investments in infrastructure. We run the following OLS regression with country-fixed effect and year dummies to capture for changes over time that are common across countries (e.g. the financial crisis):

$$
\begin{aligned}
\log P P I_{i t}=\alpha_{i} & +\beta_{1} \log \text { GDP }_{i t-1}+\beta_{2} \log \text { POP }_{i t}+\beta_{3} \log \text { GROWTH }_{i t-1} \\
& +\beta_{4} \log \text { INFLATION }_{i t-1}+\beta_{5} \log \text { OPENNESS } \\
& +\beta_{6} \log \text { DEBT }-1 \\
& +\sum \beta_{j} \log X_{i t j}+\beta_{7} \log \text { ACCESSTOFINANCE } \\
& +\sum{ }_{i t-1}
\end{aligned}
$$

Equation (8) shows that $\log P P I_{i t}$ equals logarithms of the levels of the moving average of private investment in infrastructure for country $i$ at the period $t$. Most econometric specifications dealing with GDP and Investments suffer from endogeneity. We address this problem by assuming that the investments are being affected by events of the previous year. $G D P_{i t-l}$ is the Gross Domestic Product purchasing power parity in current US millions of dollars for the country $i$ in the year $t-1$. GROWTH $H_{i t}$ ${ }_{l}$ is the GDP's growth and both are expected to have a positive impact on investment levels. $P O P_{i t}$ captures the size of the population and INFLATION ${ }_{i t-l}$ captures the monetary instability for the country $i$ in the year $t-1$ and is expected to have a negative impact. OPENNESS $S_{i t-1}$ is a proxy of the openness of the country calculated as the sum of exports and imports over the GDP; ACCESSTOFINANCE $E_{i t-1}$ captures the access to commercial bank credit for the country $i$ in the year $t-1$ and is expected to have a positive impact; and $X_{i t j}$ are the political and institutional variables including for country $i$ at time $t$ : (a) freedom from corruption; (b) government effectiveness; (c) rule of law; (d) quality of regulations; and (e) number of court disputes.

The regression results are presented in Tables 3-7. All specifications control for the main characteristics of the economies as commonly used in the previous literature:

- Size of the market: GDP and population. PPI tends to be more common in larger markets where demand is larger.

- Inflation: PPI is more prevalent in countries with more stable macroeconomic conditions. Higher inflation is less attractive for investors as it imposes an inflation risk premium.

- Openness (proxied by trade): more open countries are more likely to attract big foreign investors. 
- Debt: countries with higher levels of debt are more likely to require the private sector to invest in infrastructure. However, they could be perceived as a higher risk of default by the private sector. As a debt measure we use the total debt service divided by the gross national income.

- Access to finance, i.e. access to commercial bank credit.

Table 3 presents the results using country-fixed effect and year dummies. In these specifications, the overall R-squared is around $50 \%$, a high value for a panel data model. ${ }^{9}$

The coefficients associated with large markets, stable inflation, access to finance, freedom from corruption, rule of law, quality of regulations, and number of disputes, are statistically significant indicating that they are relevant channels for the determination of investments in PPIs.

Interestingly, the political regimens such as parliamentary democracy, mixed (semi-presidential) democracy, presidential democracy, civilian dictatorship, military dictatorship, and royal dictatorship do not affect significantly the level of PPI infrastructure investment.

Countries with large markets and high demand for infrastructure (larger population and higher lagged GDP) tend to have more PPI.

Governments with less inflation have a more stable environment fostering private sector investments in infrastructure PPIs.

The higher a country score on freedom from corruption, the higher the average level of investments with private participation in infrastructure. Decreasing corruption by 10 points can increase PPI by $6.7 \%$. That is, if a country like Serbia can lower its corruption level and become like South Africa (which has similar GDP per capita), the private sector will invest $7 \%$ more. $^{10}$

The higher a country score on rule of law, the higher the average level of investments with private participation in infrastructure. Improving rule of law by one standard deviation (i.e. by 0.1) can increase PPI by $4.3 \%$. That is, if a country like Bhutan can improve its environment of property rights and enforceability of contracts and become like Jordan (which has a similar GDP per capita), the private sector will invest $4 \%$ more. $^{11}$

Breach of contract and regulatory issues remain the most important political risk concerns for investors into developing economies, according to the annual MIGA-EIU Political Risk Survey. Forty-

\footnotetext{
${ }^{9}$ Values over $10 \%$ are accepted in the common literature, due to the bi-dimensional nature (countries and time) of the panel data model.

${ }^{10}$ In the year 2011, Serbia had a GDP per capita USD 9,687 and a freedom of corruption index of 35 while South Africa had a GDP per capita of USD 9,830 and a freedom of corruption index of 45.

${ }^{11}$ In the year 2011, Bhutan had a rule of law index of .12 and a GDP per capita of USD 5,162, while Jordan had a rule of law index of .22 with a GDP per capita of USD 5,268.
} 
five per cent of investors in developing countries named breach of contract and 58\% named adverse regulatory changes as the most important political risks they will face in the next three years. Forty per cent of the survey respondents mentioned that they experienced financial losses through adverse regulatory changes and 34\% through breach of contract over the past three years. Therefore, it is not surprising to observe that both quality of regulations and number of previous disputes are statistically significant.

The model also shows that an improvement of one standard deviation (0.1) in quality of regulation produces an average increase of $3.2 \%$ in the level of infrastructure investment in PPIs. For example, if we consider two countries with the same level of GDP per capita such as Mexico and Turkey, Mexico can gain a 3\% increase in infrastructure investment in PPIs if the country achieves the quality of regulations of Turkey. ${ }^{12}$

On disputes, the estimation indicates that the higher the number of disputes, the lower the level of investments. Having one more project going to court decreases investments by $4 \%^{13}$. We presumed that the number of disputes could have a non-linear effect on private investments (e.g. no disputes could also reflect an anticipation of risk and therefore lack of private investments); however, adding disputes squared was found to be statistically not significant. Unfortunately, the variable on time to solve a dispute was incomplete for half of the sample, impeding its proper use.

We estimate the determinants of PPI by sector to see whether the impacts vary among the energy, transport, telecom, and water sectors (see Table 4). Freedom from corruption is statistically significant for all sectors except for transport. While corruption generally reduces the prospects for investment in all sectors, the lack of sensitivity of the transport sector could be explained by the fact that corruption matters primarily regarding investors' decision to enter the transport market, not the subsequent level of investment, which may indicate that the investors are protected against such risks once they do invest.

Transport is one of the most corrupt sectors of infrastructure. Kolstad and Wiig (2013) find that "increased corruption within a country is associated with increased extractive industry FDI, but at a diminishing rate as corruption increases grow large." Thus, while threats to ownership rights deter investments into resource sectors (Bohn and Deacon 2000; Cust and Harding 2013), increased corruption would not follow this 'rule' because available measures of (perceived) corruption do not capture such a threat, because corruption has been a means of securing ownership rights, or because countries perceived as getting more corrupt offered better opportunities for FDI beyond ownership rights (such as geological prospects and reduced regulatory constraints). Although corruption may be

\footnotetext{
${ }^{12}$ In the year 2011, Mexico and Turkey had a GDP per capita of USD 12,813 and USD 13,468, respectively, while their quality of regulation indexes were .34 and .42 , respectively

${ }^{13}$ We used the number of disputes in the last 10 years before the commitment in order to capture the countries' reputation in this matter.
} 
costly, it is a cost that also offers flexibility and has helped secure deals for companies to maximize profits (Shaxson, 2007).

Rule of law is statistically significant for overall PPI, but it is not significant at the sector level. The coefficients are of almost the same magnitude but not significant due to smaller sample size when we run regressions at the sector level.

Quality of regulation is statistically significant for all sectors except water. Regulatory quality includes measures of the incidence of price controls and perceptions of the burdens imposed by excessive regulation. Improving the quality of regulations in a country can attract more private investors to infrastructure PPIs, but since water is a socially sensitive sector and very likely to be politically influenced, investors may prefer price controls and strong regulation, as they limit ex ante the risk of domestic politics around water. ${ }^{14}$

The coefficient on disputes is statistically significant for all sectors except for energy. PPI investments in telecoms and water are particularly sensitive to the accumulated number of disputes in that particular sector. Having one more dispute can decrease PPI investments in those sector by approximately $12 \%$.

Variables in institutional and political regimens such as parliamentary democracy, mixed (semi-presidential) democracy, presidential democracy, civilian dictatorship, military dictatorship, and royal dictatorship were also included as controls, but none of them was statistically significant.

As a robustness check, we have run the regressions without year dummies (see Tables 5 and 6). Insignificant changes in the main results were found.

We expected that countries with more experience on PPIs and higher income would have PPI investments less sensitive to institutional and governance variables. However, we found that results did not vary by quartile of experience, GDP and GDP per capita (see Table 7). According to field experts, it is not the quantity, but the quality of experience (i.e. successful projects) that matters, for which we do not control.

\footnotetext{
${ }^{14}$ For a robustness check, we have added the Gini coefficient as an explanatory variable, expecting that, when controlling for income inequality, the coefficient will become significant for water. However, it is still not significant.
} 


\section{Conclusions}

Fostering private-sector investment in infrastructure depends on investors facing an appropriate investment climate. Currently private sector investment is a small portion of the total infrastructure investment (less than 20\%). The costs and risks faced by investors are high, particularly in emerging market and developing economies (EMDEs) where the economic, institutional, and financial conditions are weaker and less predictable. One of the main concerns of private sector investors considering investment in infrastructure in EMDEs is the quality of the underlying investment climate.

A supportive enabling environment reduces the costs and risks of investing in infrastructure. Investment climate is affected by many factors, including political instability, regime uncertainty, ruleof-law and property rights, government regulations, government transparency, and accountability. The existence of a stable and predictable environment in which both domestic and foreign investors can operate is vital for providing confidence to investors.

This paper provides empirical evidence of the relationship between institutional, political, and governance variables and the level of PPI investments in infrastructure in developing countries. Our results support the arguments that industry and political stability are key ingredients to increase the level of PPI investments in infrastructure.

We conclude that PPI investment in infrastructure is highly sensitive to the quality of government variables such as freedom from corruption, rule of law, quality of regulations, and the number of disputes in the sector; decreasing corruption by 10 points can increase PPI by $6.7 \%$, improving rule of law by one standard deviation (i.e. by 0.1 ) can increase PPI by $4.3 \%$, improving quality of regulation by one standard deviation (0.1) produces an average increase of $3.2 \%$ in the level of infrastructure investment in PPIs, and having one more project going to court decreases investments by $4 \%$.

These results hold when data is disaggregated at the sectoral level. However, transport investments are not found to be sensitive to improvements in "freedom from corruption," water investments to improvements in quality of regulations, and energy investments to the number of accumulated disputes in the sector: more work needs to be done to understand the cause of these discrepancies.

Importantly, the evidence does not show any significant difference in the results across experience and economic level quartiles.

A sound investment climate is a critical factor affecting the supply of infrastructure investment financing. The challenges from upstream "enabling" institutions, policies, and regulations and sector economics down to pipeline development need to be addressed simultaneously. Tackling such a complex and interconnected agenda requires analysis of synergies and adoption of a holistic approach to infrastructure development. 


\section{Bibliography}

Araya G., Schwartz J., Andrés L., 2013, 'The Effects of Country Risk and Conflict on Infrastructure PPIs', World Bank Policy Research Working Paper No 6569.

Arrow K., Lind R.C., 1970, 'Uncertainty and the evaluation of public investment decisions', American Economic Review, 60, June, 364-378.

Basilio Maria, ‘Infrastructure PPP investments in Emerging Markets', REPEC, May 2011

Barnejee S. G., Oetzel J. M., Ranganathan R., 2006, 'Private Provision of Infrastructure in Emerging Markets: Do Institutions Matter?', Development Policy Review, 24 (2): 175-202

Bhattacharya A., Romani M., 2013, 'Meeting the Financing Challenge for Sustainable Infrastructure', Paper prepared for the Global Green Growth Summit 2013, Incheon City, 10-11 June.

Calderón, C., Servén L., 2004, 'The Effects of Infrastructure Development on Growth and Income Distribution', World Bank Policy Research Working Paper No 3400.

Calderón C., Servén L., 2008, 'Infrastructure and Economic Development in Sub-Saharan Africa', World Bank Policy Research Working Paper No 4712.

Calderón C., Servén L., 2010, 'Infrastructure in Latin America', World Bank Policy Research Working Paper No 5317.

Chakrabarti, A., 2001, The Determinants of Foreign Direct Investments: Sensitivity Analyses of CrossCountry Regressions. Kyklos, 54: 89-114. doi: 10.1111/1467-6435.00142

Esty B., 2011, An overview of project finance \& infrastructure-2009 update, Technical Note HBS 210061.

Fay M., Toman M., 2010, 'Infrastructure and Sustainable Development', Submitted to the Korea-World Bank High Level Conference on Post-crisis Growth and Development, co-organised by the Presidential Committee for the G20 Summit and the World Bank with the support of the Korea Institute for International Economic Policy.

FSB (Financial Stability Board), 2013, 'Financial Regulatory Factors Affecting the Availability of Longterm Investment Finance', Report to G20 Finance Ministers and Central Bank Governors.

Gasmi F., Lika B., Noumba Um P., 2010, 'Is the Level of Financial Sector Development a Key Determinant of Private Investment in the Power Sector?', TSE Working Paper Series. 
Grout P.A., 2003, 'Public and private sector discount rates in Public-Private Partnerships', The Economic Journal, 113, 486, C62-C68.

Jensen O., Blanc-Brude F., 2005, 'The Institutional Determinants of Private Sector Participation in the Water and Sanitation Sector in Developing Countries', Applied Infrastructure Research.

Hammami M., Ruhashyankiko J.F., Yehoue E. B., 2006, Determinants of Public-Private Partnerships in Infrastructure, IMF working paper, WP/06/99, International Monetary Fund.

Hart O., 2003, 'Incomplete contracts and public ownership: remarks and an application to Public-Private Partnerships', The Economic Journal, 113, 486, C69-C76.

Hart O., Shleifer A. and Vishny R.W., 1997, 'The proper scope of government: theory and an application to prisons', Quarterly Journal of Economics, 112, 4, 1127-1161.

Iossa E., Martimort D., 2011, 'Post-tender corruption and risk allocation: implications for public-private partnerships', CEIS Tor Vergata research paper series 5: 195.

Iossa E., Martimort D., 2013, ‘Corruption in PPIs, Incentives and Contract Incompleteness'.

Kirkpatrick, C., Parker D., Zhang Y., 2006, 'Foreign Direct Investment in Infrastructure in Developing Countries: Does Regulation Make a Difference?' Transnational Corporations 15, no. 1, 143-71.

MIGA, World Bank Group, 2013, 'World Investment and Political Risk 2013.' Washington DC, MIGA, WBG,

Moszoro M., 2014a, 'Efficient Public-Private Capital Structures', Annals of Public and Cooperative Economics, 85, 1, 103-126.

Moszoro M., 2014b, ‘Public-Private Monopoly', Working Paper SSRN http://dx.doi.org/10.2139/ssrn.2383309.

Moszoro M., Spiller P., 2014, 'Third-Party Opportunism and the Theory of Public Contracts: Operationalization and Applications.' In The Manufacturing of Markets: Legal, Political and Economic Dynamics, edited by Eric Brousseau and Jean-Michel Glachant. Cambridge University Press.

North D. C., Weingast B. R, 1989, 'Constitutions and commitment: the evolution of institutions governing public choice in seventeenth-century England.' Journal of Economic History 49.04 (1989): 803832.

Nunnenkamp P., Spatz J., 2002. "Determinants of FDI in Developing Countries: Has Globalization Changed the Rules of the Game? "Open Access Publications from Kiel Institute for the World Economy 2976, Kiel Institute for the World Economy (IfW).

Pragal S. 'Regulation and Private Sector Participation in Infrastructure.' Policy Research Working Paper, no. 3037 (2003). 
Straub S., 2008, 'Infrastructure and Growth in Developing Countries: Recent Advances and Research Challenges', World Bank Policy Research Working Paper No 4460.

Teorell J., Charron N., Dahlberg S., Holmberg S., Rothstein B., Sundin P., Svensson R., 2013, The Quality of Government Dataset, version 20Dec13. University of Gothenburg: The Quality of Government Institute, http://www.qog.pol.gu.se.

Tewodaj M., 2013, 'Determinants of private participation in infrastructure in low and middle income countries (LMICs)', Pardee RAND Graduate School.

UNCTAD Database of Treaty-based Investor-State Dispute Settlement Cases. This database is publicly available at: http://iiadbcases.unctad.org/

Williamson O., 1979, 'Transaction-Cost Economics: The Governance of Contractual Relations', Journal of Law and Economics, 22, 2, 233-261.

Williamson O., 1999, 'Public and private bureaucracies: a transaction cost economics perspectives', Journal of Law, Economics, and Organization, 15, 1, 306-342.

World Bank, 2013, 'Long-term Investment Financing for Growth and Development: Umbrella Paper', Presented at Meeting of the G20 Ministers of Finance and Central Bank Governors, February 2013, Moscow, Russia.

World Bank, 2013, PPI Database. http://ppi.worldbank.org 


\section{Annex I}

\section{Determinants of PPI — Literature Taxonomy and Mapping}

\begin{tabular}{|c|c|c|c|c|c|}
\hline & & \multicolumn{3}{|c|}{ Theoretical Framework } & \multirow{2}{*}{ Empirical Studies } \\
\hline & & Economics/Finance & Political Economy & $\begin{array}{l}\text { Institutional } \\
\text { Analysis }\end{array}$ & \\
\hline \multirow{9}{*}{$\frac{\frac{\mathscr{e}}{a}}{\frac{\sigma}{\sigma}}$} & Discount rate & $\begin{array}{l}\text { Social discount rate (Arrow } \\
\& \text { Lind, 1970); interest rate } \\
\text { differential (Moszoro, } \\
\text { 2014a) }\end{array}$ & \multirow{4}{*}{$\begin{array}{l}\text { Lower government beta } \\
\text { and access to capital vs. } \\
\text { investment efficiency and } \\
\text { productivity differential } \\
\text { (Grout, 2003) }\end{array}$} & & \\
\hline & Access to capital & $\begin{array}{l}\text { Access to external financing } \\
\text { (Esty, 2011) }\end{array}$ & & & \\
\hline & Investment efficiency & $\begin{array}{l}\text { Lower investment outlays } \\
\text { and shorter investment } \\
\text { period (Moszoro, 2014a) }\end{array}$ & & & \\
\hline & $\begin{array}{l}\begin{array}{l}\text { Productivity } \\
\text { differential }\end{array} \\
\end{array}$ & $\begin{array}{l}\text { Lower operational costs } \\
\text { (Moszoro, 2014b) }\end{array}$ & & & \\
\hline & Bundling & $\begin{array}{l}\text { Incentive theory and } \\
\text { economies of scope (Iossa } \\
\text { \& Martimort, 2013) }\end{array}$ & \multirow{3}{*}{$\begin{array}{l}\text { Expropriation risk and } \\
\text { LPVR (Engel, Fischer \& } \\
\text { Galetovic, 2001) }\end{array}$} & \multirow{3}{*}{$\begin{array}{l}\text { Incomplete contract theory: } \\
\text { bundling of investment and } \\
\text { operations (Hart 2003; Hart, } \\
\text { Shleifer \&Vishny 1997); } \\
\text { governance of hybrids and } \\
\text { boundaries of bureaucracy } \\
\text { (Williamson 1979, 1999) }\end{array}$} & \\
\hline & Risk allocation & \multirow{4}{*}{$\begin{array}{l}\text { Post-tender renegotiations } \\
\text { (Iossa \& Martimort, 2011) }\end{array}$} & & & \\
\hline & $\begin{array}{l}\text { Contracting flexibility } \\
\& \text { regulation }\end{array}$ & & & & \multirow{3}{*}{$\begin{array}{l}\text { Regulatory and institutional } \\
\text { framework (Pragal 2003; } \\
\text { Kirpatrick et al. 2006; Basilio } \\
\text { 2011); property right and quality } \\
\text { of the burocracy (Jensen et al. } \\
\text { 2005).; corruption and rule of } \\
\text { law (Hammami } \text { et al., 2006); } \\
\text { bureaucratic quality (Barnejee et } \\
\text { al. 2006; Gasmi } \text { et al., 2010; } \\
\text { Tewodaj, 2013) }\end{array}$} \\
\hline & $\begin{array}{l}\begin{array}{l}\text { Corruption, political } \\
\text { stability \& rule of law }\end{array} \\
\end{array}$ & & \multirow{2}{*}{\multicolumn{2}{|c|}{$\begin{array}{l}\text { Low third-party opportunism risk (Moszoro \& Spiller, } \\
\text { 2014) }\end{array}$}} & \\
\hline & Bureaucracy & & & & \\
\hline
\end{tabular}




\section{Annex II}

\section{Definition of Variables}

Quality of Government is the mean value of the ICRG variables "Corruption," "Law and Order," and "Bureaucracy Quality," scaled 0-1. Higher values indicate higher quality of government.

Freedom from Corruption relies on Transparency International's Corruption Perceptions Index (CPI), which measures the level of corruption in 152 countries to determine the freedom from corruption scores of countries that are also listed in the Index of Economic Freedom. The CPI is based on a 10-point scale, in which a score of 10 indicates very little corruption, and a score of 0 indicates a very corrupt government. In scoring freedom from corruption, the authors convert each of these raw CPI data to a 0-100 scale by multiplying the CPI scores by 10 .

Government Effectiveness combines into a single grouping responses on the quality of public service provision, the quality of the bureaucracy, the competence of civil servants, the independence of the civil service from political pressures, and the credibility of the government's commitment to policies. The main focus of this index is on the "inputs" required for the government to be able to produce and implement good policies and deliver public goods.

Rule of Law includes several indicators which measure the extent to which agents have confidence in and abide by the rules of society. These include perceptions of the incidence of crime, the effectiveness and predictability of the judiciary, and the enforceability of contracts. Together, these indicators measure the success of a society in developing an environment in which fair and predictable rules form the basis for economic and social interactions and the extent to which property rights are protected.

Regulatory Quality includes measures of the incidence of market-unfriendly policies such as price controls or inadequate bank supervision as well as perceptions of the burdens imposed by excessive regulation in areas such as foreign trade and business development.

Regimen Institutions: The classification contains the following regimes: parliamentary democracy, mixed (semi-presidential) democracy, presidential democracy, civilian dictatorship, military dictatorship, and royal dictatorship. This classification is elaborated by Cheibub, Gandhi, and Vreeland (2010). 


\section{Annex III}

Table 1. Summary Statistics

\begin{tabular}{|l|lrrrr|}
\hline Variable & Obs & \multicolumn{1}{c}{ Mean } & Std. Dev. & \multicolumn{1}{l|}{ Min } & \multicolumn{1}{c|}{ Max } \\
\hline ln GDP_1 & 7,388 & 22.76985 & 2.411881 & 15.99307 & 30.33849 \\
ln Inflation_1 & 6,588 & 1.95406 & 1.402989 & -13.4379 & 10.19474 \\
ln Trade_1 & 6,938 & 4.141784 & 0.638758 & -1.17505 & 6.13225 \\
Debt_1 & 4,242 & 4.927175 & 6.766934 & 0 & 208.0971 \\
Growth_1 & 7,140 & 2.05112 & 6.012271 & -50.2904 & 92.58597 \\
ln Population & 8,178 & 15.33762 & 2.106291 & 8.982059 & 21.01901 \\
Access to finance & 2,291 & 7.47474 & 17.92406 & 0 & 150 \\
Free of corruption & 2,987 & 40.07265 & 23.22481 & 0 & 100 \\
Government & & & & & \\
effectiveness & 2,437 & -0.05928 & 0.997779 & -2.45416 & 2.407654 \\
Rule of law & 2,492 & -0.06741 & 0.993558 & -2.67015 & 2.001923 \\
Regulatory quality & 2,438 & -0.06711 & 0.991987 & -2.67544 & 2.247345 \\
Gini coefficient & 2,710 & 41.53993 & 9.80825 & 20.96 & 74.33 \\
Disputes & 4,780 & 0.687657 & 3.303972 & 0 & 65 \\
\hline
\end{tabular}


Table 2. Correlation of Independent Variables

\begin{tabular}{|c|c|c|c|c|c|c|c|c|c|c|c|c|c|}
\hline & $\overrightarrow{0}$ & 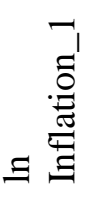 & 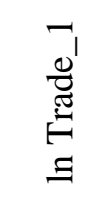 & $\begin{array}{l}\overrightarrow{1} \\
\overrightarrow{0} \\
\overrightarrow{0}\end{array}$ & 它 & 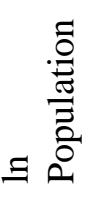 & 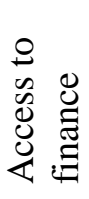 & 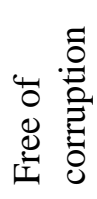 & 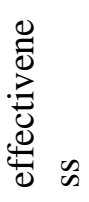 & 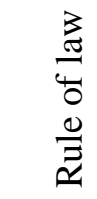 & 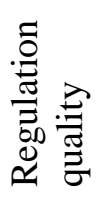 & 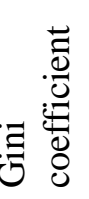 & 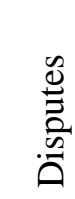 \\
\hline $\ln$ GDP_1 & 1.00 & & & & & & & & & & & & \\
\hline In Inflation_1 & 0.02 & 1.00 & & & & & & & & & & & \\
\hline ln Trade_1 & 0.30 & 0.02 & 1.00 & & & & & & & & & & \\
\hline Debt_1 & 0.01 & 0.05 & 0.19 & 1.00 & & & & & & & & & \\
\hline Growth_1 & 0.06 & 0.02 & 0.17 & 0.02 & 1.00 & & & & & & & & \\
\hline ln Population & 0.80 & 0.07 & 0.48 & 0.06 & 0.03 & 1.00 & & & & & & & \\
\hline Access to finance & 0.28 & 0.04 & 0.06 & 0.21 & 0.06 & 0.10 & 1.00 & & & & & & \\
\hline Free of corruption & 0.23 & 0.12 & 0.12 & 0.13 & 0.06 & 0.09 & 0.18 & 1.00 & & & & & \\
\hline $\begin{array}{l}\text { Government } \\
\text { effectiveness }\end{array}$ & 0.42 & $0.14^{-}$ & 0.06 & 0.08 & 0.02 & 0.10 & 0.26 & 0.72 & 1.00 & & & & \\
\hline Rule of law & 0.22 & 0.14 & 0.11 & 0.07 & 0.01 & 0.04 & 0.20 & 0.72 & 0.85 & 1.00 & & & \\
\hline Regulatory quality & 0.31 & 0.21 & 0.06 & 0.08 & 0.01 & 0.01 & 0.28 & 0.66 & 0.81 & 0.74 & 1.00 & & \\
\hline Gini coefficient & 0.04 & 0.10 & 0.09 & 0.01 & 0.20 & 0.12 & 0.02 & 0.25 & 0.22 & 0.11 & 0.25 & 1.00 & \\
\hline Disputes & 0.43 & 0.02 & 0.21 & 0.05 & 0.05 & 0.32 & 0.09 & 0.06 & 0.20 & 0.06 & 0.09 & 0.11 & 1.00 \\
\hline
\end{tabular}




\section{Main Results}

Table 3. Determinants of Private Participation in Infrastructure. Dependent Variable: Log of Total Private Investments in Infrastructure. Specification with Country Fixed Effects and Year Dummies

\begin{tabular}{|c|c|c|c|c|c|c|}
\hline VARIABLES & $\begin{array}{c}(1) \\
\ln \_ \text {PPI }\end{array}$ & $\begin{array}{c}(2) \\
\text { ln_PPI }\end{array}$ & $\begin{array}{c}(3) \\
\ln \_ \text {PPI }\end{array}$ & $\begin{array}{c}(4) \\
\ln \_ \text {PPI }\end{array}$ & $\begin{array}{c}(5) \\
\ln \_ \text {PPI }\end{array}$ & $\begin{array}{c}\text { (6) } \\
\text { ln_PPI }\end{array}$ \\
\hline ln GDP_1 & $\begin{array}{c}0.699 * * * \\
(0.145)\end{array}$ & $\begin{array}{c}0.605 * * * \\
(0.152)\end{array}$ & $\begin{array}{c}0.694 * * * \\
(0.144)\end{array}$ & $\begin{array}{c}0.104 \\
(0.180)\end{array}$ & $\begin{array}{c}0.103 \\
(0.208)\end{array}$ & $\begin{array}{c}0.579 * * * \\
(0.150)\end{array}$ \\
\hline In Inflation_1 & $\begin{array}{l}-0.0561 * \\
(0.0305)\end{array}$ & $\begin{array}{l}-0.0242 \\
(0.0309)\end{array}$ & $\begin{array}{c}-0.0504 * \\
(0.0302)\end{array}$ & $\begin{array}{l}-0.0643 * \\
(0.0331)\end{array}$ & $\begin{array}{c}-0.0732 * * \\
(0.0368)\end{array}$ & $\begin{array}{l}-0.0173 \\
(0.0305)\end{array}$ \\
\hline ln Trade_1 & $\begin{array}{l}0.0736 \\
(0.183)\end{array}$ & $\begin{array}{l}-0.147 \\
(0.186)\end{array}$ & $\begin{array}{c}0.141 \\
(0.182)\end{array}$ & $\begin{array}{l}-0.115 \\
(0.209)\end{array}$ & $\begin{array}{l}-0.150 \\
(0.230)\end{array}$ & $\begin{array}{c}-0.0775 \\
(0.184)\end{array}$ \\
\hline Debt_1 & $\begin{array}{l}-0.00509 \\
(0.00553)\end{array}$ & $\begin{array}{c}-0.000334 \\
(0.00561)\end{array}$ & $\begin{array}{l}-0.00444 \\
(0.00548)\end{array}$ & $\begin{array}{l}-6.26 \mathrm{e}-05 \\
(0.00608)\end{array}$ & $\begin{array}{l}-0.00268 \\
(0.00619)\end{array}$ & $\begin{array}{l}-2.83 e-05 \\
(0.00554)\end{array}$ \\
\hline Growth_1 & $\begin{array}{l}-0.0161 * * \\
(0.00643)\end{array}$ & $\begin{array}{l}-0.00844 \\
(0.00669)\end{array}$ & $\begin{array}{l}-0.0130 * * \\
(0.00641)\end{array}$ & $\begin{array}{c}0.00111 \\
(0.00745)\end{array}$ & $\begin{array}{l}-0.00243 \\
(0.00840)\end{array}$ & $\begin{array}{l}-0.00409 \\
(0.00668)\end{array}$ \\
\hline In Population & $\begin{array}{c}2.304 * * * \\
(0.610)\end{array}$ & $\begin{array}{l}1.434 * * \\
(0.639)\end{array}$ & $\begin{array}{c}2.062 * * * \\
(0.607)\end{array}$ & $\begin{array}{c}0.716 \\
(0.692)\end{array}$ & $\begin{array}{c}0.116 \\
(0.792)\end{array}$ & $\begin{array}{l}1.189 * \\
(0.633)\end{array}$ \\
\hline $\begin{array}{l}\text { Freedom from } \\
\text { corruption }\end{array}$ & $\begin{array}{l}0.00718^{*} \\
(0.00406)\end{array}$ & $\begin{array}{c}0.0166 * * * \\
(0.00420)\end{array}$ & $\begin{array}{l}0.00669 * \\
(0.00402)\end{array}$ & $\begin{array}{l}0.0110^{* *} \\
(0.00459)\end{array}$ & $\begin{array}{c}0.0161 * * * \\
(0.00497)\end{array}$ & $\begin{array}{c}0.0155 * * * \\
(0.00416)\end{array}$ \\
\hline $\begin{array}{l}\text { Government } \\
\text { effectiveness }\end{array}$ & $\begin{array}{l}0.0587 \\
(0.178)\end{array}$ & $\begin{array}{l}-0.107 \\
(0.180)\end{array}$ & $\begin{array}{r}0.120 \\
(0.177)\end{array}$ & $\begin{array}{l}-0.109 \\
(0.201)\end{array}$ & $\begin{array}{l}0.0178 \\
(0.215)\end{array}$ & $\begin{array}{l}-0.0461 \\
(0.179)\end{array}$ \\
\hline Rule of law & $\begin{array}{l}0.404 * * \\
(0.180)\end{array}$ & $\begin{array}{c}0.279 \\
(0.179)\end{array}$ & $\begin{array}{c}0.431 * * \\
(0.178)\end{array}$ & $\begin{array}{l}0.463 * * \\
(0.201)\end{array}$ & $\begin{array}{l}0.436 * * \\
(0.219)\end{array}$ & $\begin{array}{l}0.325^{*} \\
(0.177)\end{array}$ \\
\hline Quality of regulation & $\begin{array}{c}0.431 * * * \\
(0.152)\end{array}$ & $\begin{array}{c}0.638 * * * \\
(0.150)\end{array}$ & $\begin{array}{c}0.317 * * \\
(0.153)\end{array}$ & $\begin{array}{c}0.660 * * * \\
(0.173)\end{array}$ & $\begin{array}{c}0.598 * * * \\
(0.185)\end{array}$ & $\begin{array}{c}0.515 * * * \\
(0.150)\end{array}$ \\
\hline Access to finance & $\begin{array}{c}0.00455^{* *} * \\
(0.00196)\end{array}$ & $\begin{array}{c}0.00539 * * * \\
(0.00195)\end{array}$ & $\begin{array}{l}0.00355^{*} \\
(0.00195)\end{array}$ & $\begin{array}{c}0.00205 \\
(0.00220)\end{array}$ & $\begin{array}{c}0.00251 \\
(0.00244)\end{array}$ & $\begin{array}{c}0.00405 * * \\
(0.00195)\end{array}$ \\
\hline
\end{tabular}


Table 3. (continued) Determinants of Private Participation in Infrastructure. Dependent Variable: Log of Total Private Investments in Infrastructure. Specification with Country Fixed Effects and Year Dummies

\begin{tabular}{|c|c|c|c|c|c|c|}
\hline VARIABLES & $\begin{array}{c}(1) \\
\text { ln_PPI }\end{array}$ & $\begin{array}{c}(2) \\
\text { ln_PPI }\end{array}$ & $\begin{array}{c}(3) \\
\ln \_ \text {PPI }\end{array}$ & $\begin{array}{c}(4) \\
\ln \_ \text {PPI }\end{array}$ & $\begin{array}{c}(5) \\
\ln \_ \text {PPI }\end{array}$ & $\begin{array}{c}(6) \\
\ln \_ \text {PPI }\end{array}$ \\
\hline Gini coefficient & & $\begin{array}{c}0.00318 \\
(0.00967)\end{array}$ & & & $\begin{array}{l}0.00757 \\
(0.0116)\end{array}$ & $\begin{array}{c}-0.000675 \\
(0.00959)\end{array}$ \\
\hline $\begin{array}{l}\text { Disputes (moving } \\
\text { sum) }\end{array}$ & & & $-0.0385 * * *$ & $-0.0378 * * *$ & $-0.0350 * * *$ & $-0.0380 * * *$ \\
\hline Dispute time & & & $(0.00908)$ & $\begin{array}{c}(0.0104) \\
0.0335 \\
(0.0223)\end{array}$ & $\begin{array}{c}(0.0105) \\
0.0237 \\
(0.0227)\end{array}$ & $(0.00844)$ \\
\hline Constant & $\begin{array}{c}-50.19 * * * \\
(10.74)\end{array}$ & $\begin{array}{c}-33.81 * * * \\
(11.57)\end{array}$ & $\begin{array}{c}-46.44 * * * \\
(10.67)\end{array}$ & $\begin{array}{l}-10.15 \\
(12.26)\end{array}$ & $\begin{array}{l}-0.475 \\
(14.47)\end{array}$ & $\begin{array}{c}-29.32 * * \\
(11.46)\end{array}$ \\
\hline Observations & 1,041 & 867 & 1.041 & 771 & 651 & 867 \\
\hline R-squared & 0.487 & 0.547 & 0.497 & 0.528 & 0.540 & 0.559 \\
\hline Number of countries & 111 & 98 & 111 & 108 & 95 & 98 \\
\hline
\end{tabular}


Table 4. Determinants of Private Participation in Infrastructure by Sector. Dependent Variable: Log of Total Private Investments in Infrastructure by Sector. Specification with Country Fixed Effects and Year Dummies

\begin{tabular}{|c|c|c|c|c|c|c|c|c|}
\hline VARIABLES & $\begin{array}{c}(7) \\
\text { ln_PPI_ } \\
\text { energy }\end{array}$ & $\begin{array}{c}(8) \\
\text { ln_PPI_ } \\
\text { energy }\end{array}$ & $\begin{array}{c}(9) \\
\text { ln_PPI_ } \\
\text { energy }\end{array}$ & $\begin{array}{c}(10) \\
\text { ln_PPI_ } \\
\text { energy }\end{array}$ & $\begin{array}{c}\text { (11) } \\
\text { ln_PPI_ } \\
\text { transport }\end{array}$ & $\begin{array}{c}\text { (12) } \\
\text { ln_PPI_ } \\
\text { transport }\end{array}$ & $\begin{array}{c}(13) \\
\text { ln_PPI_ } \\
\text { transport }\end{array}$ & $\begin{array}{c}\text { (14) } \\
\text { ln_PPI_ } \\
\text { transport }\end{array}$ \\
\hline \multirow[t]{2}{*}{$\ln \mathrm{GDP}_{-} 1$} & $0.510 * *$ & $0.415 *$ & $0.506^{* *}$ & $0.406 *$ & $0.518 * *$ & 0.399 & $0.567 * *$ & $0.455^{*}$ \\
\hline & $(0.213)$ & $(0.229)$ & $(0.213)$ & $(0.229)$ & $(0.257)$ & $(0.258)$ & $(0.256)$ & $(0.258)$ \\
\hline \multirow[t]{2}{*}{ ln Inflation_1 } & -0.0349 & 0.00567 & -0.0347 & 0.00601 & $-0.0840 *$ & -0.0377 & -0.0754 & -0.0299 \\
\hline & $(0.0453)$ & $(0.0478)$ & $(0.0453)$ & $(0.0478)$ & $(0.0499)$ & $(0.0499)$ & $(0.0497)$ & $(0.0497)$ \\
\hline \multirow[t]{2}{*}{ In Trade_1 } & -0.0952 & -0.286 & -0.0910 & -0.281 & $1.337 * * *$ & $1.323 * * *$ & $1.374 * * *$ & $1.367 * * *$ \\
\hline & $(0.268)$ & $(0.285)$ & $(0.268)$ & $(0.285)$ & $(0.296)$ & $(0.300)$ & $(0.295)$ & $(0.299)$ \\
\hline \multirow[t]{3}{*}{ Debt_1 } & 0.00177 & 0.00279 & 0.00181 & 0.00282 & 0.00420 & 0.0213 & 0.00510 & 0.0217 \\
\hline & $(0.00685)$ & $(0.00749)$ & $(0.00686)$ & $(0.00749)$ & $(0.0115)$ & $(0.0146)$ & $(0.0115)$ & $(0.0145)$ \\
\hline & & & & & & & & \\
\hline Growth_1 & $\begin{array}{l}-0.0162^{*} \\
(0.00955)\end{array}$ & $\begin{array}{c}-0.00894 \\
(0.0100)\end{array}$ & $\begin{array}{c}-0.0158 \\
(0.00963)\end{array}$ & $\begin{array}{l}-0.00822 \\
(0.0101)\end{array}$ & $\begin{array}{c}0.0586 \\
(0.0113)\end{array}$ & $\begin{array}{c}0.0431 \\
(0.0116)\end{array}$ & $\begin{array}{c}0.0540 \\
(0.0114)\end{array}$ & $\begin{array}{c}0.038916 x \\
(0.0116)\end{array}$ \\
\hline \multirow[t]{2}{*}{ In Population } & $-2.214 * *$ & $-3.010 * * *$ & $-2.237 * *$ & $-3.052 * * *$ & 0.152 & -0.818 & 0.152 & -0.785 \\
\hline & $(0.988)$ & (1.070) & $(0.992)$ & $(1.073)$ & $(1.229)$ & $(1.217)$ & $(1.221)$ & $(1.211)$ \\
\hline \multirow[t]{2}{*}{ Freedom from corruption } & $0.0121 * *$ & 0.00811 & $0.0120 * *$ & 0.00782 & 0.00217 & 0.00617 & 0.00259 & 0.00688 \\
\hline & $(0.00567)$ & $(0.00605)$ & $(0.00569)$ & $(0.00608)$ & $(0.00777)$ & $(0.00801)$ & $(0.00772)$ & $(0.00797)$ \\
\hline \multicolumn{9}{|l|}{ Government } \\
\hline \multirow[t]{2}{*}{ effectiveness } & -0.218 & -0.297 & -0.217 & -0.298 & $-0.500 *$ & $-0.771 * * *$ & $-0.484 *$ & $-0.753 * *$ \\
\hline & $(0.243)$ & $(0.260)$ & $(0.243)$ & $(0.260)$ & $(0.291)$ & $(0.294)$ & $(0.290)$ & $(0.293)$ \\
\hline \multirow[t]{2}{*}{ Rule of law } & -0.115 & 0.160 & -0.112 & 0.172 & 0.359 & 0.176 & $0.501 *$ & 0.326 \\
\hline & $(0.252)$ & $(0.268)$ & $(0.253)$ & $(0.269)$ & $(0.297)$ & $(0.302)$ & $(0.301)$ & $(0.307)$ \\
\hline \multirow[t]{5}{*}{ Quality of regulation } & $0.466 * *$ & $0.460 * *$ & $0.455^{* *}$ & $0.438 *$ & $1.081 * * *$ & $1.500 * * *$ & $0.995 * * *$ & $1.415^{* * *}$ \\
\hline & $(0.214)$ & $(0.224)$ & $(0.218)$ & $(0.228)$ & $(0.236)$ & $(0.238)$ & $(0.237)$ & $(0.239)$ \\
\hline & & & & & & $0.00972 * *$ & $0.00984 * *$ & $0.00886^{* *}$ \\
\hline & $0.00553 * *$ & $0.00435 *$ & $0.00549 * *$ & $0.00426^{*}$ & $0.0108 * * *$ & $*$ & $*$ & $*$ \\
\hline & $(0.00243)$ & $(0.00250)$ & $(0.00243)$ & $(0.00250)$ & $(0.00264)$ & $(0.00257)$ & $(0.00265)$ & $(0.00259)$ \\
\hline
\end{tabular}


Table 4. (continued) Determinants of Private Participation in Infrastructure by Sector. Dependent Variable: Log of Total Private Investments in Infrastructure by Sector. Specification with Country Fixed Effects and Year Dummies

\begin{tabular}{|c|c|c|c|c|c|c|c|c|}
\hline VARIABLES & $\begin{array}{c}(7) \\
\text { ln_PPI_ } \\
\text { energy }\end{array}$ & $\begin{array}{c}(8) \\
\text { ln_PPI_ } \\
\text { energy }\end{array}$ & $\begin{array}{c}(9) \\
\text { In_PPI_ } \\
\text { energy }\end{array}$ & $\begin{array}{c}(10) \\
\text { ln_PPI_ } \\
\text { energy }\end{array}$ & $\begin{array}{c}\text { (11) } \\
\text { ln_PPI_ } \\
\text { transport }\end{array}$ & $\begin{array}{c}\text { (12) } \\
\text { ln_PPI_- } \\
\text { transport }\end{array}$ & $\begin{array}{c}(13) \\
\text { ln_PPI_ } \\
\text { transport }\end{array}$ & $\begin{array}{c}\text { (14) } \\
\text { ln_PPI_ } \\
\text { transport }\end{array}$ \\
\hline Gini coefficient & & $\begin{array}{l}0.0369 * * \\
(0.0144)\end{array}$ & & $\begin{array}{l}0.0361 * * \\
(0.0145)\end{array}$ & & $\begin{array}{c}0.0215 \\
(0.0150)\end{array}$ & & $\begin{array}{c}0.0166 \\
(0.0150)\end{array}$ \\
\hline $\begin{array}{l}\text { Number of disputes } \\
\text { energy sector }\end{array}$ & & & $\begin{array}{l}-0.00626 \\
(0.0208)\end{array}$ & $\begin{array}{l}-0.0119 \\
(0.0210)\end{array}$ & & & & \\
\hline $\begin{array}{l}\text { Number of disputes } \\
\text { transport sector }\end{array}$ & & & & & & & $\begin{array}{c}-0.0676 * * \\
(0.0262)\end{array}$ & $\begin{array}{c}-0.0589 * * \\
(0.0250)\end{array}$ \\
\hline Constant & $\begin{array}{c}27.64 \\
(17.71)\end{array}$ & $\begin{array}{l}42.96 * * \\
(19.74)\end{array}$ & $\begin{array}{c}28.09 \\
(17.79)\end{array}$ & $\begin{array}{l}43.92 * * \\
(19.82)\end{array}$ & $\begin{array}{l}-17.41 \\
(22.43)\end{array}$ & $\begin{array}{c}0.429 \\
(22.64)\end{array}$ & $\begin{array}{l}-18.76 \\
(22.31)\end{array}$ & $\begin{array}{l}-1.420 \\
(22.53)\end{array}$ \\
\hline Observations & 754 & 660 & 754 & 660 & 577 & 512 & 577 & 512 \\
\hline R-squared & 0.249 & 0.280 & 0.249 & 0.281 & 0.275 & 0.327 & 0.285 & 0.335 \\
\hline Number of countries & 87 & 75 & 87 & 75 & 76 & 67 & 76 & 67 \\
\hline ln GDP_1 & $\begin{array}{l}0.579 * * * \\
(0.152)\end{array}$ & $\begin{array}{l}0.528 * * * \\
(0.173)\end{array}$ & $\begin{array}{l}0.590 * * * \\
(0.151)\end{array}$ & $\begin{array}{c}0.529 * * * \\
(0.172)\end{array}$ & $\begin{array}{l}0.671 * * * \\
(0.250)\end{array}$ & $\begin{array}{c}0.657 * * \\
(0.263)\end{array}$ & $\begin{array}{l}0.731 * * * \\
(0.247)\end{array}$ & $\begin{array}{l}0.701 * * * \\
(0.259)\end{array}$ \\
\hline ln Inflation_1 & $\begin{array}{l}-0.0323 \\
(0.0316)\end{array}$ & $\begin{array}{l}-0.0283 \\
(0.0349)\end{array}$ & $\begin{array}{l}-0.0305 \\
(0.0315)\end{array}$ & $\begin{array}{l}-0.0249 \\
(0.0349)\end{array}$ & $\begin{array}{l}-0.00966 \\
(0.0510)\end{array}$ & $\begin{array}{l}0.00134 \\
(0.0528)\end{array}$ & $\begin{array}{l}0.00749 \\
(0.0506)\end{array}$ & $\begin{array}{l}0.0153 \\
(0.0522)\end{array}$ \\
\hline In Trade_1 & $\begin{array}{c}0.161 \\
(0.193)\end{array}$ & $\begin{array}{l}-0.0617 \\
(0.216)\end{array}$ & $\begin{array}{c}0.163 \\
(0.192)\end{array}$ & $\begin{array}{l}-0.0560 \\
(0.215)\end{array}$ & $\begin{array}{l}1.441 * * * \\
(0.324)\end{array}$ & $\begin{array}{l}1.134 * * * \\
(0.337)\end{array}$ & $\begin{array}{c}1.627 * * * \\
(0.324)\end{array}$ & $\begin{array}{c}1.328 * * * \\
(0.339)\end{array}$ \\
\hline Debt_1 & $\begin{array}{c}0.00187 \\
(0.00577)\end{array}$ & $\begin{array}{c}0.00583 \\
(0.00625)\end{array}$ & $\begin{array}{c}0.00278 \\
(0.00577)\end{array}$ & $\begin{array}{c}0.00618 \\
(0.00624)\end{array}$ & $\begin{array}{c}0.0118 \\
(0.0101)\end{array}$ & $\begin{array}{l}0.0255^{*} \\
(0.0152)\end{array}$ & $\begin{array}{c}0.0120 \\
(0.00999)\end{array}$ & $\begin{array}{l}0.0255 * \\
(0.0150)\end{array}$ \\
\hline Growth_1 & $\begin{array}{c}0.00335 \\
(0.00669)\end{array}$ & $\begin{array}{c}0.00173 \\
(0.00759)\end{array}$ & $\begin{array}{c}0.00436 \\
(0.00669)\end{array}$ & $\begin{array}{c}0.00334 \\
(0.00761)\end{array}$ & $\begin{array}{c}-0.0251 * * \\
(0.0110)\end{array}$ & $\begin{array}{l}-0.0211^{*} \\
(0.0115)\end{array}$ & $\begin{array}{c}-0.0189^{*} \\
(0.0110)\end{array}$ & $\begin{array}{c}-0.0141 \\
(0.0116)\end{array}$ \\
\hline ln Population & $\begin{array}{c}2.572 * * * \\
(0.653)\end{array}$ & $\begin{array}{l}1.904 * * \\
(0.741)\end{array}$ & $\begin{array}{c}2.649 * * * \\
(0.653)\end{array}$ & $\begin{array}{c}1.912 * * * \\
(0.740)\end{array}$ & $\begin{array}{c}-2.784 * * \\
(1.250)\end{array}$ & $\begin{array}{c}-2.941 * * \\
(1.313)\end{array}$ & $\begin{array}{c}-2.920 * * \\
(1.232)\end{array}$ & $\begin{array}{c}-2.938 * * \\
(1.293)\end{array}$ \\
\hline
\end{tabular}

Marian Moszoro et al. — Discussion Paper 2014-15 — @ C OECD/ITF 2014 
Table 4. (continued) Determinants of Private Participation in Infrastructure by Sector. Dependent Variable: Log of Total Private Investments in Infrastructure by Sector. Specification with Country Fixed Effects and Year Dummies

\begin{tabular}{|c|c|c|c|c|c|c|c|c|}
\hline VARIABLES & $\begin{array}{c}(7) \\
\text { ln_PPI_- } \\
\text { energy }\end{array}$ & $\begin{array}{c}(8) \\
\text { ln_PPI_ } \\
\text { energy }\end{array}$ & $\begin{array}{c}(9) \\
\text { ln_PPI_ } \\
\text { energy }\end{array}$ & $\begin{array}{c}(10) \\
\text { ln_PPI_ } \\
\text { energy }\end{array}$ & $\begin{array}{c}(11) \\
\text { ln_PPI_ } \\
\text { transport }\end{array}$ & $\begin{array}{c}(12) \\
\text { ln_PPI_- } \\
\text { transport }\end{array}$ & $\begin{array}{c}\text { (13) } \\
\text { ln_PPI_ } \\
\text { transport }\end{array}$ & $\begin{array}{c}(14) \\
\text { ln_PPI_- } \\
\text { transport }\end{array}$ \\
\hline $\begin{array}{l}\text { Freedom from } \\
\text { corruption }\end{array}$ & $\begin{array}{l}0.0129 * * * \\
(0.00450)\end{array}$ & $\begin{array}{l}0.0231 * * * \\
(0.00497)\end{array}$ & $\begin{array}{l}0.0129 * * * \\
(0.00449)\end{array}$ & $\begin{array}{c}0.0229 * * * \\
(0.00496)\end{array}$ & $\begin{array}{l}0.0165 * * \\
(0.00745)\end{array}$ & $\begin{array}{l}0.0161 * * \\
(0.00815)\end{array}$ & $\begin{array}{l}0.0164 * * \\
(0.00734)\end{array}$ & $\begin{array}{l}0.0154 * \\
(0.00803)\end{array}$ \\
\hline $\begin{array}{l}\text { Government } \\
\text { effectiveness }\end{array}$ & $\begin{array}{c}-0.294 \\
(0.189)\end{array}$ & $\begin{array}{l}-0.321 \\
(0.205)\end{array}$ & $\begin{array}{l}-0.258 \\
(0.189)\end{array}$ & $\begin{array}{l}-0.277 \\
(0.206)\end{array}$ & $\begin{array}{c}0.239 \\
(0.338)\end{array}$ & $\begin{array}{c}0.414 \\
(0.359)\end{array}$ & $\begin{array}{c}0.324 \\
(0.334)\end{array}$ & $\begin{array}{c}0.483 \\
(0.355)\end{array}$ \\
\hline Rule of Law & $\begin{array}{l}0.350 * \\
(0.192)\end{array}$ & $\begin{array}{c}0.276 \\
(0.207)\end{array}$ & $\begin{array}{c}0.298 \\
(0.193)\end{array}$ & $\begin{array}{c}0.234 \\
(0.208)\end{array}$ & $\begin{array}{c}0.296 \\
(0.298)\end{array}$ & $\begin{array}{c}0.339 \\
(0.306)\end{array}$ & $\begin{array}{c}0.357 \\
(0.294)\end{array}$ & $\begin{array}{c}0.395 \\
(0.302)\end{array}$ \\
\hline Quality of regulation & $\begin{array}{c}0.548 * * * \\
(0.159)\end{array}$ & $\begin{array}{c}0.570 * * * \\
(0.170)\end{array}$ & $\begin{array}{c}0.566^{* * * *} \\
(0.159)\end{array}$ & $\begin{array}{c}0.579 * * * \\
(0.170)\end{array}$ & $\begin{array}{c}-0.183 \\
(0.231)\end{array}$ & $\begin{array}{c}-0.208 \\
(0.248)\end{array}$ & $\begin{array}{l}-0.285 \\
(0.230)\end{array}$ & $\begin{array}{c}-0.298 \\
(0.246)\end{array}$ \\
\hline Access to finance & $\begin{array}{c}0.00155 \\
(0.00203) \\
\end{array}$ & $\begin{array}{c}0.00237 \\
(0.00219) \\
\end{array}$ & $\begin{array}{c}0.00115 \\
(0.00203) \\
\end{array}$ & $\begin{array}{c}0.00194 \\
(0.00220) \\
\end{array}$ & $\begin{array}{l}0.000438 \\
(0.00271)\end{array}$ & $\begin{array}{r}-0.000832 \\
(0.00285) \\
\end{array}$ & $\begin{array}{l}-4.93 \mathrm{e}-05 \\
(0.00268) \\
\end{array}$ & $\begin{array}{l}-0.00135 \\
(0.00281)\end{array}$ \\
\hline Gini coefficient & & $\begin{array}{l}-0.0122 \\
(0.0112)\end{array}$ & & $\begin{array}{l}-0.0124 \\
(0.0112)\end{array}$ & & $\begin{array}{c}0.0178 \\
(0.0171)\end{array}$ & & $\begin{array}{c}0.0205 \\
(0.0169)\end{array}$ \\
\hline $\begin{array}{l}\text { Number of disputes } \\
\text { Number of disputes } \\
\text { telecom sector }\end{array}$ & & & $\begin{array}{l}-0.142 * * \\
(0.0614)\end{array}$ & $\begin{array}{l}-0.141 * * \\
(0.0689)\end{array}$ & & & & \\
\hline $\begin{array}{l}\text { Number of disputes } \\
\text { water sector }\end{array}$ & & & & & & & $\begin{array}{c}-0.122 * * * \\
(0.0399)\end{array}$ & $\begin{array}{c}-0.120 * * * \\
(0.0406)\end{array}$ \\
\hline Constant & $\begin{array}{c}-53.31 * * * \\
(11.49)\end{array}$ & $\begin{array}{l}-40.45^{* * *} \\
(13.35)\end{array}$ & $\begin{array}{c}-54.85 * * * \\
(11.48)\end{array}$ & $\begin{array}{l}-40.63 * * * \\
(13.32)\end{array}$ & $\begin{array}{c}26.47 \\
(24.30)\end{array}$ & $\begin{array}{c}30.14 \\
(25.63)\end{array}$ & $\begin{array}{c}26.43 \\
(23.94)\end{array}$ & $\begin{array}{c}27.98 \\
(25.25)\end{array}$ \\
\hline Observations & 977 & 821 & 977 & 821 & 334 & 308 & 334 & 308 \\
\hline R-squared & 0.493 & 0.492 & 0.496 & 0.495 & 0.452 & 0.473 & 0.470 & 0.490 \\
\hline Number of countries & 106 & 91 & 106 & 91 & 40 & 36 & 40 & 36 \\
\hline
\end{tabular}

Marian Moszoro et al. — Discussion Paper 2014-15 — @ OECD/ITF 2014 
Table 5. Determinants of Private Participation in Infrastructure. Dependent Variable: Log of Total Private Investments in Infrastructure. Specification with Country Fixed Effects (No Year Dummies)

\begin{tabular}{|c|c|c|c|c|c|c|}
\hline VARIABLES & $\begin{array}{c}(1) \\
\ln \_ \text {PPI }\end{array}$ & $\begin{array}{c}(2) \\
\text { ln_PPI }\end{array}$ & $\begin{array}{c}(3) \\
\text { ln_PPI }\end{array}$ & $\begin{array}{c}(4) \\
\text { ln_PPI }\end{array}$ & $\begin{array}{c}(5) \\
\ln \_ \text {PPI }\end{array}$ & $\begin{array}{c}(6) \\
\text { ln_PPI }\end{array}$ \\
\hline ln GDP_1 & $\begin{array}{c}0.830 * * * \\
(0.0795)\end{array}$ & $\begin{array}{c}0.843 * * * \\
(0.0798)\end{array}$ & $\begin{array}{c}0.863 * * * \\
(0.0801)\end{array}$ & $\begin{array}{c}0.801 * * * \\
(0.0942)\end{array}$ & $\begin{array}{c}0.856^{* * * *} \\
(0.101)\end{array}$ & $\begin{array}{c}0.874 * * * \\
(0.0803)\end{array}$ \\
\hline In Inflation_1 & $\begin{array}{c}-0.138 * * * \\
(0.0284)\end{array}$ & $\begin{array}{c}-0.137 * * * \\
(0.0288)\end{array}$ & $\begin{array}{c}-0.140 * * * \\
(0.0283)\end{array}$ & $\begin{array}{c}-0.148 * * * \\
(0.0313)\end{array}$ & $\begin{array}{c}-0.171 * * * \\
(0.0338)\end{array}$ & $\begin{array}{c}-0.141 * * * \\
(0.0287)\end{array}$ \\
\hline In Trade_1 & $\begin{array}{l}0.298 * \\
(0.170)\end{array}$ & $\begin{array}{c}0.201 \\
(0.178)\end{array}$ & $\begin{array}{c}0.366^{* * *} \\
(0.171)\end{array}$ & $\begin{array}{c}0.296 \\
(0.204)\end{array}$ & $\begin{array}{c}0.311 \\
(0.228)\end{array}$ & $\begin{array}{c}0.273 \\
(0.179)\end{array}$ \\
\hline Debt_1 & $\begin{array}{l}0.000734 \\
(0.00562)\end{array}$ & $\begin{array}{c}0.00780 \\
(0.00581)\end{array}$ & $\begin{array}{c}0.00130 \\
(0.00560)\end{array}$ & $\begin{array}{c}0.00493 \\
(0.00635)\end{array}$ & $\begin{array}{c}0.00396 \\
(0.00643)\end{array}$ & $\begin{array}{c}0.00805 \\
(0.00579)\end{array}$ \\
\hline Growth_1 & $\begin{array}{l}-0.0128 * * \\
(0.00631)\end{array}$ & $\begin{array}{c}-0.00323 \\
(0.00652)\end{array}$ & $\begin{array}{l}-0.0113^{*} \\
(0.00631)\end{array}$ & $\begin{array}{l}-0.00323 \\
(0.00750)\end{array}$ & $\begin{array}{c}-0.00163 \\
(0.00824)\end{array}$ & $\begin{array}{c}-0.00153 \\
(0.00653)\end{array}$ \\
\hline In Population & $\begin{array}{c}4.337 * * * \\
(0.497)\end{array}$ & $\begin{array}{c}4.466 * * * \\
(0.524)\end{array}$ & $\begin{array}{c}4.401 * * * \\
(0.496)\end{array}$ & $\begin{array}{c}4.245^{* * * *} \\
(0.590)\end{array}$ & $\begin{array}{c}3.999 * * * \\
(0.674)\end{array}$ & $\begin{array}{c}4.569 * * * \\
(0.523)\end{array}$ \\
\hline $\begin{array}{l}\text { Freedom from } \\
\text { corruption }\end{array}$ & $\begin{array}{l}0.00720 * \\
(0.00417)\end{array}$ & $\begin{array}{c}0.0159 * * * \\
(0.00442)\end{array}$ & $\begin{array}{l}0.00692 * \\
(0.00416)\end{array}$ & $\begin{array}{l}0.0111^{* *} \\
(0.00484)\end{array}$ & $\begin{array}{c}0.0169 * * * \\
(0.00527)\end{array}$ & $\begin{array}{c}0.0153 * * * \\
(0.00441)\end{array}$ \\
\hline $\begin{array}{l}\text { Government } \\
\text { effectiveness }\end{array}$ & $\begin{array}{c}0.197 \\
(0.182)\end{array}$ & $\begin{array}{c}0.124 \\
(0.188)\end{array}$ & $\begin{array}{c}0.241 \\
(0.182)\end{array}$ & $\begin{array}{l}-0.109 \\
(0.210)\end{array}$ & $\begin{array}{c}0.120 \\
(0.226)\end{array}$ & $\begin{array}{c}0.171 \\
(0.188)\end{array}$ \\
\hline Rule of law & $\begin{array}{c}0.387 * * \\
(0.183)\end{array}$ & $\begin{array}{c}0.267 \\
(0.187)\end{array}$ & $\begin{array}{c}0.395 * * \\
(0.182)\end{array}$ & $\begin{array}{l}0.408 * \\
(0.209)\end{array}$ & $\begin{array}{c}0.466 * * \\
(0.227)\end{array}$ & $\begin{array}{c}0.285 \\
(0.186)\end{array}$ \\
\hline Quality of regulation & $\begin{array}{c}0.227 \\
(0.153)\end{array}$ & $\begin{array}{c}0.419 * * * \\
(0.155)\end{array}$ & $\begin{array}{c}0.140 \\
(0.155)\end{array}$ & $\begin{array}{c}0.465 * * * \\
(0.178)\end{array}$ & $\begin{array}{c}0.388 * * \\
(0.192)\end{array}$ & $\begin{array}{c}0.332 * * \\
(0.158)\end{array}$ \\
\hline Access to finance & $\begin{array}{c}0.00126 \\
(0.00154) \\
\end{array}$ & $\begin{array}{c}0.00211 \\
(0.00162) \\
\end{array}$ & $\begin{array}{l}0.000943 \\
(0.00153) \\
\end{array}$ & $\begin{array}{c}0.00246 \\
(0.00185) \\
\end{array}$ & $\begin{array}{c}0.00239 \\
(0.00207) \\
\end{array}$ & $\begin{array}{c}0.00174 \\
(0.00162)\end{array}$ \\
\hline
\end{tabular}


Table 5. (continued) Determinants of Private Participation in Infrastructure. Dependent Variable: Log of Total Private Investments in Infrastructure. Specification with Country Fixed Effects (No Year Dummies)

\begin{tabular}{|c|c|c|c|c|c|c|}
\hline VARIABLES & $\begin{array}{c}(1) \\
\ln \text { PPI }\end{array}$ & $\begin{array}{c}(2) \\
\ln \text { PPI }\end{array}$ & $\begin{array}{c}(3) \\
\ln \text { PPI }\end{array}$ & $\begin{array}{c}(4) \\
\ln \text { PPI }\end{array}$ & $\begin{array}{c}(5) \\
\ln \text { PPI }\end{array}$ & $\begin{array}{c}(6) \\
\ln \text { PPI }\end{array}$ \\
\hline Gini coefficient & & $\begin{array}{l}0.00454 \\
(0.0100)\end{array}$ & & & $\begin{array}{l}0.00257 \\
(0.0120)\end{array}$ & $\begin{array}{l}0.00139 \\
(0.0101)\end{array}$ \\
\hline Number of disputes & & & $\begin{array}{c}-0.0256 * * * \\
(0.00917)\end{array}$ & $\begin{array}{c}-0.0234 * * \\
(0.0109)\end{array}$ & $\begin{array}{c}-0.0214 * * \\
(0.0109)\end{array}$ & $\begin{array}{c}-0.0237 * * * \\
(0.00872)\end{array}$ \\
\hline Dispute time & & & & $\begin{array}{c}0.0755 * * * \\
(0.0226)\end{array}$ & $\begin{array}{c}0.0653 * * * \\
(0.0230)\end{array}$ & \\
\hline Constant & $\begin{array}{c}-86.38 * * * \\
(6.838)\end{array}$ & $\begin{array}{c}-89.73 * * * \\
(7.458)\end{array}$ & $\begin{array}{c}-88.43 * * * \\
(6.853)\end{array}$ & $\begin{array}{c}-83.75 * * * \\
(8.221)\end{array}$ & $\begin{array}{c}-81.97 * * * \\
(9.777)\end{array}$ & $\begin{array}{c}-92.26 * * * \\
(7.484)\end{array}$ \\
\hline Observations & 1.041 & 867 & 1.041 & 771 & 651 & 867 \\
\hline R-squared & 0.446 & 0.483 & 0.451 & 0.458 & 0.468 & 0.488 \\
\hline Number of countries & 111 & 98 & 111 & 108 & 95 & 98 \\
\hline
\end{tabular}


Table 6. Determinants of Private Participation in Infrastructure by Sector. Dependent Variable: Log of Total Private Investments in Infrastructure by Sector. Specification with Country Fixed Effects (No Year Dummies)

\begin{tabular}{|c|c|c|c|c|c|c|c|c|}
\hline VARIABLES & $\begin{array}{c}(7) \\
\text { ln_PPI_ } \\
\text { energy }\end{array}$ & $\begin{array}{c}(8) \\
\text { ln_PPI_ } \\
\text { energy }\end{array}$ & $\begin{array}{c}(9) \\
\text { ln_PPI_ } \\
\text { energy }\end{array}$ & $\begin{array}{c}(10) \\
\text { ln_PPI_ } \\
\text { energy }\end{array}$ & $\begin{array}{c}\text { (11) } \\
\text { ln_PPI_ } \\
\text { transport }\end{array}$ & $\begin{array}{c}\text { (12) } \\
\text { ln_PPI_ } \\
\text { transport }\end{array}$ & $\begin{array}{c}\text { (13) } \\
\text { ln_PPI_ } \\
\text { transport }\end{array}$ & $\begin{array}{c}\text { (14) } \\
\text { ln_PPI_ } \\
\text { transport }\end{array}$ \\
\hline ln GDP_1 & $\begin{array}{c}0.625 * * * \\
(0.111)\end{array}$ & $\begin{array}{c}0.688^{* * *} \\
(0.115)\end{array}$ & $\begin{array}{c}0.624 * * * \\
(0.112)\end{array}$ & $\begin{array}{c}0.685 * * * \\
(0.115)\end{array}$ & $\begin{array}{c}0.515 * * * \\
(0.133)\end{array}$ & $\begin{array}{c}0.556 * * * \\
(0.130)\end{array}$ & $\begin{array}{c}0.532 * * * \\
(0.133)\end{array}$ & $\begin{array}{c}0.569 * * * \\
(0.130)\end{array}$ \\
\hline ln Inflation_1 & $\begin{array}{c}-0.130 * * * \\
(0.0421)\end{array}$ & $\begin{array}{c}-0.116^{* *} \\
(0.0448)\end{array}$ & $\begin{array}{c}-0.130 * * * \\
(0.0422)\end{array}$ & $\begin{array}{c}-0.115^{* *} \\
(0.0449)\end{array}$ & $\begin{array}{l}-0.115^{* * *} \\
(0.0452)\end{array}$ & $\begin{array}{c}-0.0886 * * \\
(0.0449)\end{array}$ & $\begin{array}{c}-0.117 * * * \\
(0.0450)\end{array}$ & $\begin{array}{c}-0.0907 * * \\
(0.0448)\end{array}$ \\
\hline In Trade_1 & $\begin{array}{c}0.344 \\
(0.244)\end{array}$ & $\begin{array}{c}0.232 \\
(0.262)\end{array}$ & $\begin{array}{c}0.341 \\
(0.246)\end{array}$ & $\begin{array}{c}0.226 \\
(0.264)\end{array}$ & $\begin{array}{c}1.500 * * * \\
(0.272)\end{array}$ & $\begin{array}{c}1.489 * * * \\
(0.274)\end{array}$ & $\begin{array}{c}1.516 * * * \\
(0.271)\end{array}$ & $\begin{array}{c}1.505 * * * \\
(0.273)\end{array}$ \\
\hline Debt_1 & $\begin{array}{c}0.00716 \\
(0.00703)\end{array}$ & $\begin{array}{c}0.00859 \\
(0.00767)\end{array}$ & $\begin{array}{c}0.00715 \\
(0.00704)\end{array}$ & $\begin{array}{c}0.00859 \\
(0.00767)\end{array}$ & $\begin{array}{c}0.0128 \\
(0.0114)\end{array}$ & $\begin{array}{c}0.0353 * * \\
(0.0143)\end{array}$ & $\begin{array}{c}0.0137 \\
(0.0114)\end{array}$ & $\begin{array}{c}0.0360 * * \\
(0.0142)\end{array}$ \\
\hline $\begin{array}{l}\text { Growth_1 } \\
\text { In Population }\end{array}$ & $\begin{array}{c}-0.0116 \\
(0.00903) \\
1.395^{*} \\
(0.771) \\
\end{array}$ & $\begin{array}{c}-0.00905 \\
(0.00937) \\
1.414^{*} \\
(0.833) \\
\end{array}$ & $\begin{array}{c}-0.0116 \\
(0.00907) \\
1.392 * \\
(0.773) \\
\end{array}$ & $\begin{array}{c}-0.00920 \\
(0.00940) \\
1.403 * \\
(0.836) \\
\end{array}$ & $\begin{array}{c}-0.0491 * * * \\
(0.0101) \\
0.843 \\
(0.918)\end{array}$ & $\begin{array}{c}-0.0393 * * * \\
(0.00999) \\
0.816 \\
(0.890) \\
\end{array}$ & $\begin{array}{c}-0.0467 * * * \\
(0.0101) \\
0.974 \\
(0.917)\end{array}$ & $\begin{array}{c}-0.0375 * * * \\
(0.0100) \\
0.923 \\
(0.889) \\
\end{array}$ \\
\hline $\begin{array}{l}\text { Freedom from } \\
\text { corruption }\end{array}$ & $\begin{array}{l}0.00996^{*} \\
(0.00587)\end{array}$ & $\begin{array}{c}0.00747 \\
(0.00629)\end{array}$ & $\begin{array}{l}0.00998^{*} \\
(0.00588)\end{array}$ & $\begin{array}{c}0.00756 \\
(0.00631)\end{array}$ & $\begin{array}{c}0.00173 \\
(0.00779)\end{array}$ & $\begin{array}{c}0.00551 \\
(0.00800)\end{array}$ & $\begin{array}{c}0.00222 \\
(0.00776)\end{array}$ & $\begin{array}{c}0.00601 \\
(0.00798)\end{array}$ \\
\hline $\begin{array}{l}\text { Government } \\
\text { effectiveness }\end{array}$ & $\begin{array}{c}0.00755 \\
(0.248)\end{array}$ & $\begin{array}{c}-0.0750 \\
(0.267)\end{array}$ & $\begin{array}{c}0.00752 \\
(0.248)\end{array}$ & $\begin{array}{r}-0.0744 \\
(0.267)\end{array}$ & $\begin{array}{c}-0.296 \\
(0.290)\end{array}$ & $\begin{array}{c}-0.505 * \\
(0.291)\end{array}$ & $\begin{array}{l}-0.263 \\
(0.289)\end{array}$ & $\begin{array}{c}-0.472 \\
(0.291)\end{array}$ \\
\hline Rule of law & $\begin{array}{r}-0.0307 \\
(0.260)\end{array}$ & $\begin{array}{c}0.164 \\
(0.277)\end{array}$ & $\begin{array}{c}-0.0314 \\
(0.260)\end{array}$ & $\begin{array}{c}0.161 \\
(0.277)\end{array}$ & $\begin{array}{c}0.310 \\
(0.296)\end{array}$ & $\begin{array}{l}0.0489 \\
(0.297)\end{array}$ & $\begin{array}{c}0.415 \\
(0.298)\end{array}$ & $\begin{array}{c}0.150 \\
(0.302)\end{array}$ \\
\hline Quality of regulation & $\begin{array}{c}0.125 \\
(0.215)\end{array}$ & $\begin{array}{l}0.0560 \\
(0.226)\end{array}$ & $\begin{array}{c}0.128 \\
(0.219)\end{array}$ & $\begin{array}{l}0.0649 \\
(0.231)\end{array}$ & $\begin{array}{c}0.888 * * * \\
(0.232)\end{array}$ & $\begin{array}{c}1.296 * * * \\
(0.233)\end{array}$ & $\begin{array}{c}0.808 * * * \\
(0.234)\end{array}$ & $\begin{array}{c}1.226 * * * \\
(0.236)\end{array}$ \\
\hline Access to finance & $\begin{array}{l}0.000128 \\
(0.00189)\end{array}$ & $\begin{array}{c}0.00139 \\
(0.00201)\end{array}$ & $\begin{array}{l}0.000128 \\
(0.00189)\end{array}$ & $\begin{array}{c}0.00139 \\
(0.00201)\end{array}$ & $\begin{array}{l}0.00368 * \\
(0.00191)\end{array}$ & $\begin{array}{c}0.00496 * * \\
(0.00194)\end{array}$ & $\begin{array}{l}0.00327 * \\
(0.00191)\end{array}$ & $\begin{array}{c}0.00456 * * \\
(0.00195)\end{array}$ \\
\hline
\end{tabular}

34 Marian Moszoro et al. — Discussion Paper 2014-15 — @ OECD/ITF 2014 
Table 6. (continued) Determinants of Private Participation in Infrastructure by Sector. Dependent Variable: Log of Total Private Investments in Infrastructure by Sector. Specification with Country Fixed Effects (No Year Dummies)

\begin{tabular}{|c|c|c|c|c|c|c|c|c|}
\hline VARIABLES & $\begin{array}{c}(7) \\
\text { ln_PPI_ } \\
\text { energy }\end{array}$ & $\begin{array}{c}(8) \\
\text { ln_PPI_ } \\
\text { energy }\end{array}$ & $\begin{array}{c}(9) \\
\text { ln_PPI_ } \\
\text { energy }\end{array}$ & $\begin{array}{c}(10) \\
\text { ln_PPI_ } \\
\text { energy }\end{array}$ & $\begin{array}{c}\text { (11) } \\
\text { ln_PPI_ } \\
\text { transport }\end{array}$ & $\begin{array}{c}\text { (12) } \\
\text { ln_PPI_ } \\
\text { transport }\end{array}$ & $\begin{array}{c}\text { (13) } \\
\text { ln_PPI_ } \\
\text { transport }\end{array}$ & $\begin{array}{c}\text { (14) } \\
\text { ln_PPI_ } \\
\text { transport }\end{array}$ \\
\hline Gini coefficient & & $\begin{array}{c}0.0520 * * * \\
(0.0146)\end{array}$ & & $\begin{array}{c}0.0524 * * * \\
(0.0147)\end{array}$ & & $\begin{array}{l}0.0297 * * \\
(0.0148)\end{array}$ & & $\begin{array}{l}0.0265^{*} \\
(0.0149)\end{array}$ \\
\hline $\begin{array}{l}\text { Number of disputes } \\
\text { energy sector }\end{array}$ & & & $\begin{array}{l}0.00178 \\
(0.0212)\end{array}$ & $\begin{array}{l}0.00431 \\
(0.0214)\end{array}$ & & & & \\
\hline $\begin{array}{l}\text { Number of disputes } \\
\text { transport sector }\end{array}$ & & & & & & & $\begin{array}{c}-0.0579 * * \\
(0.0262)\end{array}$ & $\begin{array}{l}-0.0452^{*} \\
(0.0248)\end{array}$ \\
\hline Constant & $\begin{array}{c}-35.66 * * * \\
(10.97) \\
754\end{array}$ & $\begin{array}{c}-39.25 * * * \\
(12.10)\end{array}$ & $\begin{array}{c}-35.57 * * * \\
(11.03)\end{array}$ & $\begin{array}{c}-38.98 * * * \\
(12.18)\end{array}$ & $\begin{array}{c}-29.01 * * \\
(13.19) \\
577\end{array}$ & $\begin{array}{c}-31.27 * * \\
(12.99)\end{array}$ & $\begin{array}{c}-31.63 * * \\
(13.19)\end{array}$ & $\begin{array}{l}-33.28 * * \\
(13.01)\end{array}$ \\
\hline $\begin{array}{l}\text { Observations } \\
\text { R-squared }\end{array}$ & $\begin{array}{c}754 \\
0.170\end{array}$ & $\begin{array}{c}660 \\
0.196\end{array}$ & $\begin{array}{c}754 \\
0.170\end{array}$ & $\begin{array}{c}660 \\
0.196\end{array}$ & $\begin{array}{c}577 \\
0.230\end{array}$ & $\begin{array}{c}512 \\
0.285\end{array}$ & $\begin{array}{c}577 \\
0.238\end{array}$ & $\begin{array}{c}512 \\
0.291\end{array}$ \\
\hline Number of countries & 87 & 75 & 87 & 75 & 76 & 67 & 76 & 67 \\
\hline $\ln$ GDP_1 & $\begin{array}{l}0.860 * * * \\
(0.0809)\end{array}$ & $\begin{array}{l}0.872 * * * \\
(0.0874)\end{array}$ & $\begin{array}{c}0.870 * * * \\
(0.0811)\end{array}$ & $\begin{array}{l}0.878 * * * \\
(0.0878)\end{array}$ & $\begin{array}{c}0.474 * * * \\
(0.122)\end{array}$ & $\begin{array}{c}0.519 * * * \\
(0.128)\end{array}$ & $\begin{array}{c}0.485 * * * \\
(0.123)\end{array}$ & $\begin{array}{c}0.529 * * * \\
(0.129)\end{array}$ \\
\hline ln Inflation_1 & $\begin{array}{c}-0.0993 * * * \\
(0.0293)\end{array}$ & $\begin{array}{c}-0.114 * * * \\
(0.0319)\end{array}$ & $\begin{array}{c}-0.101 * * * \\
(0.0293)\end{array}$ & $\begin{array}{c}-0.115 * * * \\
(0.0320)\end{array}$ & $\begin{array}{l}-0.125 * * \\
(0.0500)\end{array}$ & $\begin{array}{l}-0.117 * * \\
(0.0519)\end{array}$ & $\begin{array}{l}-0.126 * * \\
(0.0500)\end{array}$ & $\begin{array}{l}-0.118 * * \\
(0.0520)\end{array}$ \\
\hline In Trade_1 & $\begin{array}{l}0.404 * * \\
(0.176)\end{array}$ & $\begin{array}{c}0.295 \\
(0.200)\end{array}$ & $\begin{array}{l}0.414 * * \\
(0.176)\end{array}$ & $\begin{array}{c}0.304 \\
(0.200)\end{array}$ & $\begin{array}{l}1.690 * * * \\
(0.284)\end{array}$ & $\begin{array}{l}1.395^{* * * *} \\
(0.307)\end{array}$ & $\begin{array}{l}1.734 * * * \\
(0.295)\end{array}$ & $\begin{array}{c}1.445^{* * *} \\
(0.318)\end{array}$ \\
\hline Debt_1 & $\begin{array}{c}0.00559 \\
(0.00579)\end{array}$ & $\begin{array}{c}0.0114 * \\
(0.00629)\end{array}$ & $\begin{array}{c}0.00631 \\
(0.00581)\end{array}$ & $\begin{array}{c}0.0116^{*} \\
(0.00629)\end{array}$ & $\begin{array}{l}0.0180 * \\
(0.0105)\end{array}$ & $\begin{array}{c}0.0407 * * * \\
(0.0156)\end{array}$ & $\begin{array}{l}0.0182^{*} \\
(0.0106)\end{array}$ & $\begin{array}{c}0.0412 * * * \\
(0.0156)\end{array}$ \\
\hline Growth_1 & $\begin{array}{r}-0.000759 \\
(0.00645)\end{array}$ & $\begin{array}{l}-8.70 \mathrm{e}-05 \\
(0.00717)\end{array}$ & $\begin{array}{l}-3.02 \mathrm{e}-05 \\
(0.00647)\end{array}$ & $\begin{array}{l}0.000437 \\
(0.00721)\end{array}$ & $\begin{array}{c}-0.0332 * * * \\
(0.0102)\end{array}$ & $\begin{array}{c}-0.0289 * * * \\
(0.0106)\end{array}$ & $\begin{array}{c}-0.0326 * * * \\
(0.0103)\end{array}$ & $\begin{array}{c}-0.0282 * * * \\
(0.0106)\end{array}$ \\
\hline In Population & $\begin{array}{c}4.505 * * * \\
(0.538)\end{array}$ & $\begin{array}{c}4.383 * * * \\
(0.607)\end{array}$ & $\begin{array}{c}4.629 * * * \\
(0.545)\end{array}$ & $\begin{array}{c}4.449 * * * \\
(0.614)\end{array}$ & $\begin{array}{c}0.187 \\
(0.932)\end{array}$ & $\begin{array}{c}0.761 \\
(0.999)\end{array}$ & $\begin{array}{c}0.278 \\
(0.946)\end{array}$ & $\begin{array}{c}0.896 \\
(1.024)\end{array}$ \\
\hline
\end{tabular}


Table 6. (continued) Determinants of Private Participation in Infrastructure by Sector. Dependent Variable: Log of Total Private Investments in Infrastructure by Sector. Specification with Country Fixed Effects (No Year Dummies)

\begin{tabular}{|c|c|c|c|c|c|c|c|c|}
\hline VARIABLES & $\begin{array}{c}(7) \\
\text { ln_PPI_ } \\
\text { energy }\end{array}$ & $\begin{array}{c}(8) \\
\text { ln_PPI_ } \\
\text { energy }\end{array}$ & $\begin{array}{c}(9) \\
\text { ln_PPI_ } \\
\text { energy }\end{array}$ & $\begin{array}{c}(10) \\
\text { ln_PPI_ } \\
\text { energy }\end{array}$ & $\begin{array}{c}\text { (11) } \\
\text { ln_PPI_ } \\
\text { transport }\end{array}$ & $\begin{array}{c}\text { (12) } \\
\text { ln_PPI_ } \\
\text { transport }\end{array}$ & $\begin{array}{c}\text { (13) } \\
\text { ln_PPI_ } \\
\text { transport }\end{array}$ & $\begin{array}{c}\text { (14) } \\
\text { ln_PPI_ } \\
\text { transport }\end{array}$ \\
\hline Freedom corruption & $\begin{array}{l}0.0132 * * * \\
(0.00457)\end{array}$ & $\begin{array}{c}0.0235 * * * \\
(0.00507)\end{array}$ & $\begin{array}{c}0.0132 * * * \\
(0.00457)\end{array}$ & $\begin{array}{c}0.0234 * * * \\
(0.00507)\end{array}$ & $\begin{array}{l}0.0174 * * \\
(0.00777)\end{array}$ & $\begin{array}{c}0.0149 * \\
(0.00850)\end{array}$ & $\begin{array}{l}0.0175^{* *} \\
(0.00778)\end{array}$ & $\begin{array}{c}0.0147 * \\
(0.00852)\end{array}$ \\
\hline $\begin{array}{l}\text { Government } \\
\text { effectiveness }\end{array}$ & $\begin{array}{c}-0.174 \\
(0.190)\end{array}$ & $\begin{array}{l}-0.117 \\
(0.207)\end{array}$ & $\begin{array}{l}-0.146 \\
(0.190)\end{array}$ & $\begin{array}{c}-0.0966 \\
(0.209)\end{array}$ & $\begin{array}{l}0.669 * \\
(0.346)\end{array}$ & $\begin{array}{c}0.760 * * \\
(0.369)\end{array}$ & $\begin{array}{c}0.702 * * \\
(0.351)\end{array}$ & $\begin{array}{c}0.792 * * \\
(0.373)\end{array}$ \\
\hline Rule of law & $\begin{array}{c}0.278 \\
(0.194)\end{array}$ & $\begin{array}{c}0.206 \\
(0.210)\end{array}$ & $\begin{array}{c}0.247 \\
(0.195)\end{array}$ & $\begin{array}{c}0.191 \\
(0.211)\end{array}$ & $\begin{array}{l}0.603 * \\
(0.308)\end{array}$ & $\begin{array}{c}0.641 * * \\
(0.318)\end{array}$ & $\begin{array}{c}0.622 * * \\
(0.310)\end{array}$ & $\begin{array}{c}0.659 * * \\
(0.320)\end{array}$ \\
\hline Quality of regulation & $\begin{array}{c}0.423 * * * \\
(0.158)\end{array}$ & $\begin{array}{c}0.401 * * \\
(0.171)\end{array}$ & $\begin{array}{c}0.426 * * * \\
(0.158)\end{array}$ & $\begin{array}{c}0.399 * * \\
(0.171)\end{array}$ & $\begin{array}{c}-0.545^{* *} \\
(0.233)\end{array}$ & $\begin{array}{c}-0.569 * * \\
(0.250)\end{array}$ & $\begin{array}{c}-0.577 * * \\
(0.240)\end{array}$ & $\begin{array}{c}-0.602 * * \\
(0.256)\end{array}$ \\
\hline Access to finance & $\begin{array}{c}0.00175 \\
(0.00158) \\
\end{array}$ & $\begin{array}{c}0.00174 \\
(0.00177) \\
\end{array}$ & $\begin{array}{c}0.00145 \\
(0.00159) \\
\end{array}$ & $\begin{array}{c}0.00161 \\
(0.00178)\end{array}$ & $\begin{array}{c}-0.00415 * * \\
(0.00189)\end{array}$ & $\begin{array}{c}-0.00539 * * * \\
(0.00204)\end{array}$ & $\begin{array}{c}-0.00422^{* *} * \\
(0.00190)\end{array}$ & $\begin{array}{c}-0.00544 * * * \\
(0.00204)\end{array}$ \\
\hline Gini coefficient & & $\begin{array}{l}-0.0145 \\
(0.0113)\end{array}$ & & $\begin{array}{l}-0.0146 \\
(0.0113)\end{array}$ & & $\begin{array}{l}0.0315 * \\
(0.0177)\end{array}$ & & $\begin{array}{l}0.0321 * \\
(0.0178)\end{array}$ \\
\hline $\begin{array}{l}\text { Number of disputes } \\
\text { telecom sector }\end{array}$ & & & $\begin{array}{l}-0.0869 \\
(0.0614)\end{array}$ & $\begin{array}{l}-0.0498 \\
(0.0692)\end{array}$ & & & & \\
\hline $\begin{array}{l}\text { Number of disputes } \\
\text { water sector }\end{array}$ & & & & & & & $\begin{array}{c}-0.0238 \\
(0.0404)\end{array}$ & $\begin{array}{c}-0.0260 \\
(0.0417)\end{array}$ \\
\hline Constant & $\begin{array}{l}-91.61 * * * \\
(7.488)\end{array}$ & $\begin{array}{l}-89.87 * * * \\
(8.700)\end{array}$ & $\begin{array}{l}-93.89 * * * \\
(7.656)\end{array}$ & $\begin{array}{c}-91.12 * * * \\
(8.873)\end{array}$ & $\begin{array}{l}-19.26 \\
(14.14)\end{array}$ & $\begin{array}{l}-30.47 * \\
(15.64)\end{array}$ & $\begin{array}{l}-21.22 \\
(14.54)\end{array}$ & $\begin{array}{l}-33.24 * * \\
(16.27)\end{array}$ \\
\hline Observations & 977 & 821 & 977 & 821 & 334 & 308 & 334 & 308 \\
\hline R-squared & 0.465 & 0.454 & 0.466 & 0.455 & 0.352 & 0.367 & 0.353 & 0.368 \\
\hline Number of countries & 106 & 91 & 106 & 91 & 40 & 36 & 40 & 36 \\
\hline
\end{tabular}

36 Marian Moszoro et al. - Discussion Paper 2014-15 — @ OECD/ITF 2014 
Table 7. Determinants of Private Participation in Infrastructure by Quartile of Experience and GDP. Dependent Variable: Log of Total Private Investments in Infrastructure by Quartile of Experience and GDP. Specification with Country Fixed Effects and Year Dummies

\begin{tabular}{|c|c|c|c|c|c|c|c|c|c|c|c|c|}
\hline & \multicolumn{4}{|c|}{ EXPERIENCE } & \multicolumn{4}{|c|}{ GDP } & \multicolumn{4}{|c|}{ GDP per capita } \\
\hline VARIABLES & $\begin{array}{c}(1) \\
\ln \_ \text {PPI }\end{array}$ & $\begin{array}{c}(2) \\
\ln \_ \text {PPI }\end{array}$ & $\begin{array}{c}(3) \\
\ln \_ \text {PPI }\end{array}$ & $\begin{array}{c}(4) \\
\ln \_ \text {PPI }\end{array}$ & $\begin{array}{c}(1) \\
\ln \_ \text {PPI }\end{array}$ & $\begin{array}{c}(2) \\
\ln \_ \text {PPI }\end{array}$ & $\begin{array}{c}(3) \\
\ln \_ \text {PPI }\end{array}$ & $\begin{array}{c}(4) \\
\ln \_ \text {PPI }\end{array}$ & $\begin{array}{c}(1) \\
\ln \_ \text {PPI }\end{array}$ & $\begin{array}{c}(2) \\
\ln \_ \text {PPI }\end{array}$ & $\begin{array}{c}(3) \\
\ln \_ \text {PPI }\end{array}$ & $\begin{array}{c}(4) \\
\ln \_ \text {PPI }\end{array}$ \\
\hline ln GDP_1 & $\begin{array}{c}-2.818 * * * \\
(0.802)\end{array}$ & $\begin{array}{l}-0.260 \\
(0.422)\end{array}$ & $\begin{array}{c}1.360 * * * \\
(0.382)\end{array}$ & $\begin{array}{c}0.662 * * * \\
(0.141)\end{array}$ & $\begin{array}{l}-1.111 \\
(0.839)\end{array}$ & $\begin{array}{c}0.218 \\
(0.399)\end{array}$ & $\begin{array}{c}1.361 * * * \\
(0.253)\end{array}$ & $\begin{array}{c}0.870 * * * \\
(0.241)\end{array}$ & $\begin{array}{c}0.395 \\
(0.464)\end{array}$ & $\begin{array}{c}1.458 * * * \\
(0.286)\end{array}$ & $\begin{array}{l}0.592 * * \\
(0.259)\end{array}$ & $\begin{array}{c}0.855 * * * \\
(0.312)\end{array}$ \\
\hline In Inflation_1 & $\begin{array}{l}-0.0446 \\
(0.0996)\end{array}$ & $\begin{array}{c}0.0228 \\
(0.0480)\end{array}$ & $\begin{array}{l}-0.118^{*} \\
(0.0672)\end{array}$ & $\begin{array}{l}-0.00677 \\
(0.0294)\end{array}$ & $\begin{array}{l}-0.0748 \\
(0.144)\end{array}$ & $\begin{array}{l}-0.0610 \\
(0.0701)\end{array}$ & $\begin{array}{c}-0.121 * * * \\
(0.0457)\end{array}$ & $\begin{array}{c}0.0200 \\
(0.0523)\end{array}$ & $\begin{array}{c}0.0107 \\
(0.0809)\end{array}$ & $\begin{array}{c}0.0394 \\
(0.0461)\end{array}$ & $\begin{array}{l}0.00834 \\
(0.0539)\end{array}$ & $\begin{array}{c}-0.148 * * * \\
(0.0543)\end{array}$ \\
\hline ln Trade_1 & $\begin{array}{c}-4.217 * * * \\
(1.006)\end{array}$ & $\begin{array}{c}-1.226 * * * \\
(0.385)\end{array}$ & $\begin{array}{c}0.338 \\
(0.506)\end{array}$ & $\begin{array}{l}0.318^{*} \\
(0.175)\end{array}$ & $\begin{array}{l}-1.613 \\
(0.994)\end{array}$ & $\begin{array}{c}-1.135^{* *} \\
(0.457)\end{array}$ & $\begin{array}{c}0.449 \\
(0.310)\end{array}$ & $\begin{array}{c}0.668 * * \\
(0.315)\end{array}$ & $\begin{array}{c}0.148 \\
(0.377)\end{array}$ & $\begin{array}{c}-0.989 * * * \\
(0.306)\end{array}$ & $\begin{array}{l}-0.275 \\
(0.330)\end{array}$ & $\begin{array}{c}1.743 * * * \\
(0.481)\end{array}$ \\
\hline Debt_1 & $\begin{array}{c}0.0969 * * \\
(0.0452)\end{array}$ & $\begin{array}{c}0.0119 \\
(0.0221)\end{array}$ & $\begin{array}{l}-0.00242 \\
(0.00633)\end{array}$ & $\begin{array}{l}0.000204 \\
(0.00719)\end{array}$ & $\begin{array}{c}0.00247 \\
(0.00857)\end{array}$ & $\begin{array}{c}0.0398 \\
(0.0286)\end{array}$ & $\begin{array}{c}-0.0296 * * \\
(0.0124)\end{array}$ & $\begin{array}{l}0.00572 \\
(0.0138)\end{array}$ & $\begin{array}{c}0.00175 \\
(0.00752)\end{array}$ & $\begin{array}{c}0.0242 \\
(0.0176)\end{array}$ & $\begin{array}{c}0.0201 \\
(0.0189)\end{array}$ & $\begin{array}{l}-0.0202 * \\
(0.0114)\end{array}$ \\
\hline Growth_1 & $\begin{array}{c}-0.0420 * * \\
(0.0208)\end{array}$ & $\begin{array}{l}-0.0210 * \\
(0.0123)\end{array}$ & $\begin{array}{c}- \\
0.0354 * * * \\
(0.0121)\end{array}$ & $\begin{array}{l}-0.00495 \\
(0.00634)\end{array}$ & $\begin{array}{l}-0.0140 \\
(0.0250)\end{array}$ & $\begin{array}{c}-0.00375 \\
(0.0136)\end{array}$ & $\begin{array}{c}0.0443 * * * \\
(0.0126)\end{array}$ & $\begin{array}{l}-0.0108 \\
(0.0108)\end{array}$ & $\begin{array}{c}0.0274 \\
(0.0186)\end{array}$ & $\begin{array}{l}-0.00949 \\
(0.00995)\end{array}$ & $\begin{array}{r}-0.0217 * * \\
(0.00982)\end{array}$ & $\begin{array}{c}- \\
0.0653 * * * \\
(0.0128)\end{array}$ \\
\hline ln Population & 0.792 & -0.822 & $3.914 *$ & -0.397 & $6.224 * *$ & 1.256 & $7.124 * * *$ & 0.254 & $6.589 * *$ & $6.065 * * *$ & -0.103 & $-3.833^{* *}$ \\
\hline & $(6.280)$ & (2.706) & $(2.350)$ & $(0.801)$ & $(2.948)$ & $(1.548)$ & $(1.177)$ & $(1.220)$ & $(2.976)$ & $(1.269)$ & $(1.035)$ & $(1.506)$ \\
\hline & -0.0361 & 0.00768 & -0.00848 & $-0.00907 *$ & $0.0459 *$ & 0.0171 & $0.0120^{*}$ & $0.0168 * *$ & 0.00433 & 0.00494 & 0.00869 & -0.00896 \\
\hline $\begin{array}{l}\text { Freedom from } \\
\text { corruption }\end{array}$ & $(0.0221)$ & $(0.00901)$ & $(0.0104)$ & $(0.00544)$ & $(0.0230)$ & $(0.0104)$ & $(0.00673)$ & $(0.00703)$ & $(0.00987)$ & $(0.00730)$ & $(0.00650)$ & $(0.00780)$ \\
\hline & -0.315 & -0.300 & 0.522 & 0.0248 & 0.676 & -0.0960 & $1.527 * * *$ & -0.440 & -0.0386 & 0.405 & 0.179 & 0.509 \\
\hline $\begin{array}{l}\text { Government } \\
\text { effectiveness }\end{array}$ & $(0.688)$ & $(0.438)$ & $(0.476)$ & $(0.191)$ & $(0.735)$ & $(0.468)$ & $(0.340)$ & $(0.282)$ & $(0.489)$ & $(0.279)$ & $(0.275)$ & $(0.384)$ \\
\hline & -0.102 & -0.101 & 0.679 & 0.110 & 1.090 & 0.288 & $1.144 * * *$ & -0.175 & 0.193 & 0.110 & 0.287 & $0.812 * *$ \\
\hline Rule of law & $(0.724)$ & $(0.394)$ & $(0.467)$ & $(0.182)$ & $(0.771)$ & $(0.474)$ & $(0.333)$ & $(0.270)$ & $(0.412)$ & $(0.307)$ & $(0.292)$ & $(0.388)$ \\
\hline & -0.137 & 0.216 & -0.0276 & $0.648 * * *$ & -1.302 & 0.384 & $-0.688 * * *$ & $0.731 * * *$ & -0.192 & $0.729 * * *$ & 0.320 & -0.137 \\
\hline
\end{tabular}


Table 7. (continued) Determinants of Private Participation in Infrastructure by Quartile of Experience and GDP. Dependent Variable: Log of Total Private Investments in Infrastructure by Quartile of Experience and GDP. Specification with Country Fixed Effects and Year Dummies

\begin{tabular}{|c|c|c|c|c|c|c|c|c|c|c|c|c|}
\hline & \multicolumn{4}{|c|}{ EXPERIENCE } & \multicolumn{4}{|c|}{ GDP } & \multicolumn{4}{|c|}{ GDP per capita } \\
\hline VARIABLES & $\begin{array}{c}(1) \\
\ln \_ \text {PPI }\end{array}$ & $\begin{array}{c}(2) \\
\ln \_ \text {PPI }\end{array}$ & $\begin{array}{c}(3) \\
\ln \_\mathrm{PPI} \\
\end{array}$ & $\begin{array}{c}(4) \\
\ln \_ \text {PPI }\end{array}$ & $\begin{array}{c}(1) \\
\ln \_ \text {PPI }\end{array}$ & $\begin{array}{c}(2) \\
\ln \_ \text {PPI }\end{array}$ & $\begin{array}{c}(3) \\
\ln \_ \text {PPI }\end{array}$ & $\begin{array}{c}(4) \\
\ln \_ \text {PPI }\end{array}$ & $\begin{array}{c}(1) \\
\ln \_ \text {PPI }\end{array}$ & $\begin{array}{c}(2) \\
\ln \_ \text {PPI }\end{array}$ & $\begin{array}{c}(3) \\
\ln \_ \text {PPI }\end{array}$ & $\begin{array}{c}\text { (4) } \\
\ln \_ \text {PPI }\end{array}$ \\
\hline $\begin{array}{l}\text { Quality of } \\
\text { regulation }\end{array}$ & $\begin{array}{c}(0.541) \\
0.00586\end{array}$ & $\begin{array}{c}(0.394) \\
-0.000321\end{array}$ & $\begin{array}{c}(0.351) \\
0.000102\end{array}$ & $\begin{array}{c}(0.151) \\
0.00173\end{array}$ & $\begin{array}{c}(0.894) \\
0.0255\end{array}$ & $\begin{array}{c}(0.459) \\
0.00472\end{array}$ & $\begin{array}{c}(0.236) \\
-0.00287\end{array}$ & $\begin{array}{c}(0.222) \\
0.00637 * *\end{array}$ & $\begin{array}{c}(0.390) \\
0.0215^{* *}\end{array}$ & $\begin{array}{c}(0.278) \\
0.00503\end{array}$ & $\begin{array}{c}(0.236) \\
0.00303\end{array}$ & $\begin{array}{c}(0.271) \\
0.00501\end{array}$ \\
\hline $\begin{array}{l}\text { Access to } \\
\text { finance }\end{array}$ & $(0.00601)$ & $(0.00608)$ & $(0.00435)$ & $(0.00157)$ & $(0.0178)$ & $(0.00629)$ & $(0.00328)$ & $(0.00255)$ & (0.00925) & (0.00309) & (0.00348) & $(0.00327)$ \\
\hline Constant & $\begin{array}{c}69.54 \\
(98.53)\end{array}$ & $\begin{array}{c}25.25 \\
(40.77)\end{array}$ & $\begin{array}{c}-89.58 * * \\
(39.31)\end{array}$ & $\begin{array}{c}-4.662 \\
(14.84)\end{array}$ & $\begin{array}{l}-55.09 \\
(43.07)\end{array}$ & $\begin{array}{l}-17.75 \\
(26.06)\end{array}$ & $\begin{array}{c}-141.5 * * * \\
(19.90)\end{array}$ & $\begin{array}{c}-24.02 \\
(23.85)\end{array}$ & $\begin{array}{c}-114.8 * * \\
(46.29)\end{array}$ & $\begin{array}{c}-125.5 * * * \\
(23.02)\end{array}$ & $\begin{array}{l}-7.397 \\
(18.15)\end{array}$ & $\begin{array}{c}40.06 \\
(28.19)\end{array}$ \\
\hline Observations & 120 & 206 & 320 & 392 & 90 & 234 & 341 & 365 & 184 & 267 & 245 & 334 \\
\hline $\begin{array}{l}\text { R-squared } \\
\text { Number of } \\
\text { countries }\end{array}$ & $\begin{array}{c}0.661 \\
55\end{array}$ & $\begin{array}{c}0.461 \\
79\end{array}$ & 0.227 & 0.499 & 0.580 & 0.494 & 0.610 & 0.494 & 0.635 & 0.750 & $\begin{array}{c}0.579 \\
39\end{array}$ & $\begin{array}{c}0.410 \\
43\end{array}$ \\
\hline
\end{tabular}


